\title{
TRABAJOS RECIENTES EN XCARET, QUINTANA ROO
}

\author{
María José CoN \\ Centro Regional Quintana Roo \\ INAH
}

\section{INTRODUCCIÓN}

Hace ya más de dos décadas que el ahora estado de Quintana Roo, como parte de la política económica del país, ha venido desarrollándose turísticamente en forma acelerada, especialmente en la franja costera norte y centro del estado, convirtiendo al Caribe mexicano en uno de los principales polos turísticos a nivel nacional e internacional.

Este crecimiento se tradujo en la construcción masiva de obras de infraestructura turística, principalmente, que generaron cambios significativos en la estructura económica, social y cultural de la comunidad lugareña. Asimismo, la alteración al medio natural tanto terrestre como marino es en muchos casos irreversible.

Este proyecto arqueológico, como la mayoría de los realizados por arqueólogos mexicanos en los últimos años, responde a estas transformaciones y a la inminente necesidad de recuperar la mayor cantidad de datos arqueológicos que desaparecen día con día. Si bien es cierto que por una parte estas obras permiten en algunos casos la obtención de fondos para la investigación, por otra, las zonas arqueológicas quedan en su mayoría "cautivas" dentro de las instalaciones turísticas como son los jardines de un hotel o un campo de golf. Esto lleva en ocasiones a pensar si en lugar de que un adoratorio maya quede en el hoyo 10 de un campo de golf, no sería más digno que sucumbiera bajo el peso de un trascabo. 
El presente trabajo resume dos temporadas de campo llevadas a cabo durante los meses de agosto a diciembre de 1986 y de julio a noviembre de 1987, en el sitio arqueológico de Xcaret, Quintana Roo. Colaboraron Guillermo Goñi Motilla, Luis Alberto Martos, Alejandro Tovalín Ahumada, José Carlos Beltrán Medina y Rodrigo Liendo Stuardo, así como albañiles de Oxkutzcab, Yucatán y trabajadores de Playa del Carmen, Quintana Roo.

El proyecto surgió como respuesta a un desarrollo turístico a pequeña escala que se realiza en las inmediaciones de la zona arqueológica, de ahí la necesidad de una delimitación del sitio y de la consolidación de los grupos de estructuras que por encontrarse cerca de la caleta y el cenote (que han hecho de Xcaret un sitio muy visitado), repercutía en la estabilidad de las estructuras mismas.

Quisiera dar las gracias en especial al señor Miguel Quintana Pali, bajo cuyos auspicios se realizó el proyecto y cuyo entusiasmo y colaboración hizo más fácil los momentos difíciles. A Daniel Ortega, por iluminarme en el tortuoso mundo administrativo, a Sara Novelo por su ayuda incondicional. Al ingeniero Alejandro Arístiguez quien realizó la retícula del área e hizo posible la recolocación del dintel del edificio A-VI. A Guillermo, Luis Alberto, Alejandro, José Carlos y Rodrigo mis colaboradores y amigos. Al señor Juan Delgado, propietario del Rancho Xcaret.

Gracias a los magos de la consolidación y mis maestros en el arte de la cal y el cemento, todos ellos de Oxkutzcab: Antonio Ucán A., Asunción Cámara C. (maestro Cuñas), Feliciano Gómez C., Diego Puc P., Eulogio Salazar G. y Gonzalo Herrera F. También a los trabajadores de Playa del Carmen, don José Candelario C., Ramón Chan M., Mauro Cocom P., Martiniano Pech T., Francisco Pérez T., Antonio, Venustiano y Julián Mahla E., con todos ellos compartí sudor y keyem.

\section{Generalidades}

\section{a) Localización}

El sitio arqueológico de Xcaret, municipio de Cozumel, se encuentra localizado en la costa oriental de la península de Yu- 


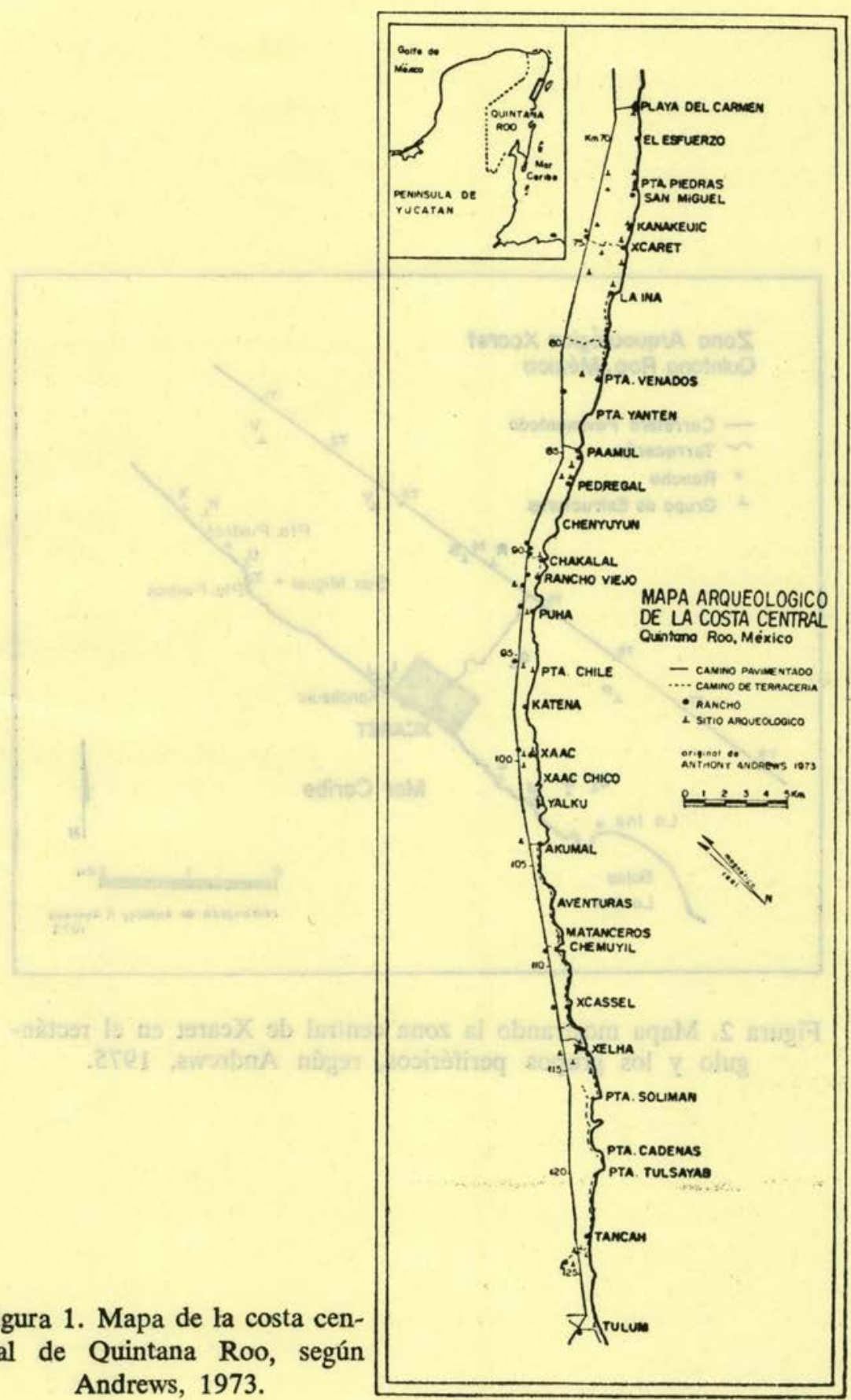




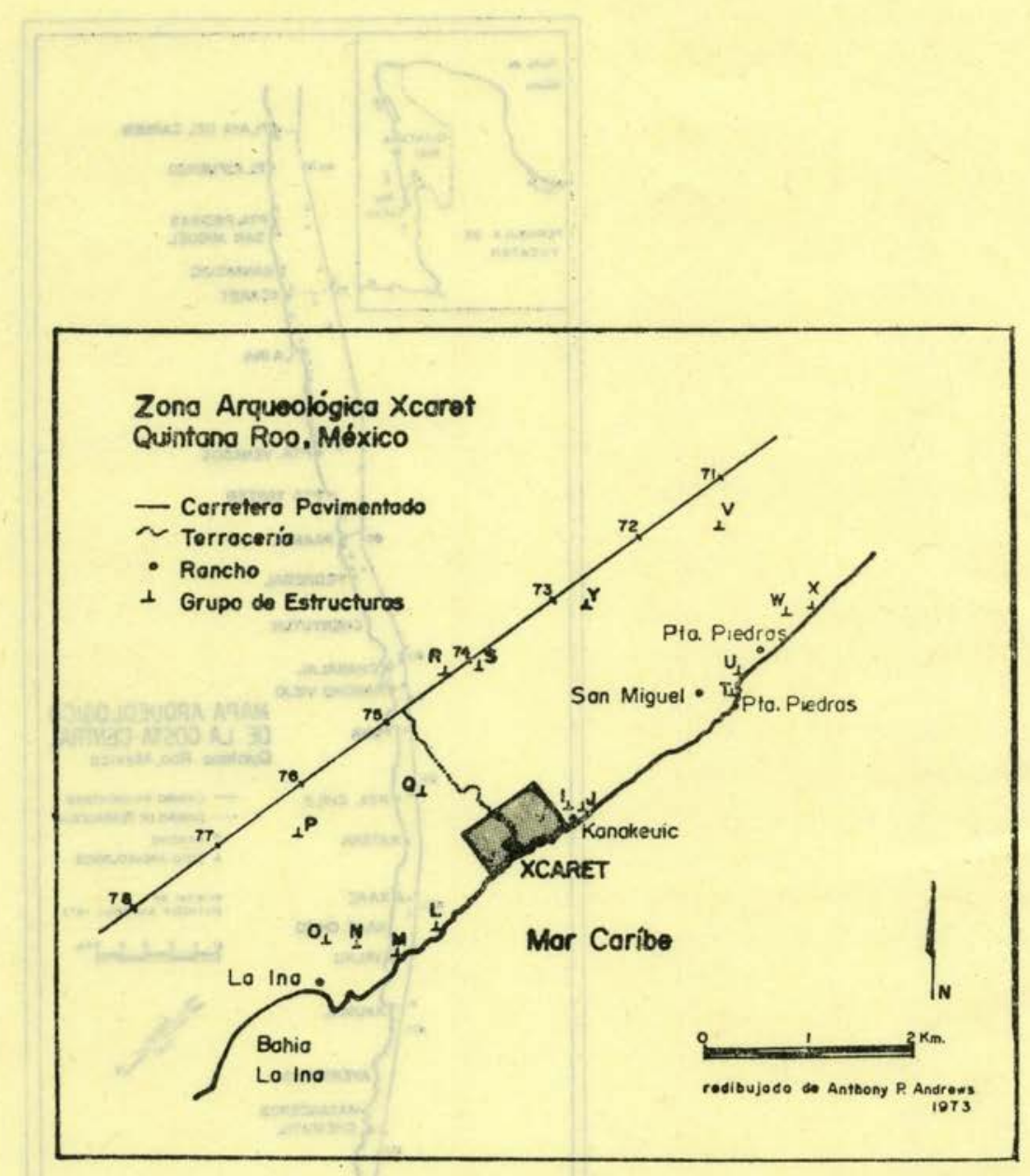

Figura 2. Mapa mostrando la zona central de Xcaret en el rectángulo y los grupos periféricos, según Andrews, 1975. 
catán, en el estado de Quintana Roo. Sus coordenadas geográficas son $20^{\circ} 35^{\prime} 4^{\prime \prime}$ de latitud norte y $87^{\circ} 06^{\prime}$ de longitud oeste (fig 1).

Aproximadamente en el kilómetro 74.8 de la carretera federal 307, que une Puerto Juárez con Chetumal, sale una desviación hacia el mar que conduce a la parte central del sitio arqueológico y a la caleta. El poblado más cercano es Playa del Carmen a $6 \mathrm{~km}$ al norte (fig 2).

\section{b) Geomorfología}

Geológicamente la península de Yucatán corresponde a una gran planicie calcárea de origen marino, que hace treinta millones de años era un mar somero. Dicha superficie terrestre emergió lentamente. Esta plataforma caliza bajo la acción de las lluvias y corrientes de agua dio origen a cavernosidades subterráneas. Así, la porción norte de la península, a diferencia de la del sur, permaneció entera sin permitir el afloramiento de ríos.

Estas condiciones físicas sólo permitieron la formación de un suelo poco profundo con escasa capacidad humítica, lo cual no to hace muy adecuado para el cultivo intensivo.

Una característica importante de estos suelos calcáreos y determinante en cuanto al aprovisionamiento de agua, la constituyen una serie de formaciones kársticas como son las depresiones naturales que se dan por hundimientos locales. Las más comunes las forman las aguadas, con agua permanente que puede contener aguas pluviales en caso de impermeabilidad del fondo, por azolves arcillosos o la presencia de aguas freáticas (Sánchez Crispín, 1980). En ocasiones esta impermeabilización fue hecha por el hombre para retener el líquido vital para su supervivencia.

Los cenotes son otras formas kársticas subterráneas básicas para la dotación de agua fresca. Los más comunes en las inmediaciones de Xcaret son en forma de caverna con entrada lateral y la parte con agua provista de techo.

Fisiográficamente el litoral coralífero del noreste, donde se asienta Xcaret, está caracterizado por formaciones coralinas fósiles formadas durante el Pleistoceno y que sobresalen entre 
$50 \mathrm{~cm}$ y $1 \mathrm{~m}$ sobre el nivel del agua (lám. $1 \mathrm{~b}$ ), procurando blancas y finas arenas en las porciones donde hay playa. La costa coralina se rompe en algunas partes de la costa, para dar entrada al mar formando caletas que ofrecen protección natural a embarcaciones pequeñas, como es el caso de la caleta de Xcaret que tiene de 1 a $3 \mathrm{~m}$ de profundidad (lám. 1a).

El Mar Caribe que baña la costa quintanarroense, tiene un arrecife coralino que se extiende a todo lo largo del litoral. La plataforma continental es de poca profundidad entre la playa y el arrecife, incrementando drásticamente después de él.

\section{c) Clima}

La región a la que hacemos referencia, pertenece a la categoría de los climas cálidos subhúmedos con lluvias en verano. Según la clasificación de Koëppen, corresponde al más húmedo de los subhúmedos $\mathrm{AW}_{2}\left(\mathrm{X}^{\prime}\right)$, con lluvias promedio anuales de $1300 \mathrm{~mm}$, y una temperatura media de $26^{\circ} \mathrm{C}$. La época de

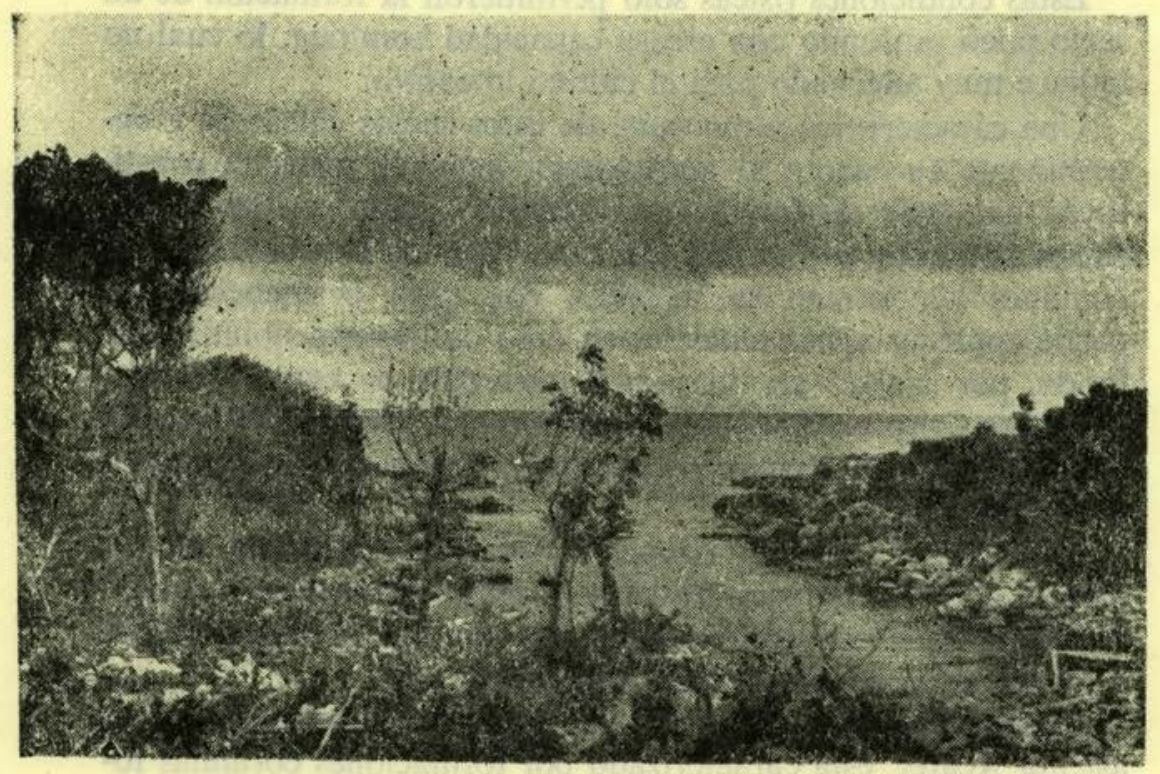

Lámina 1a. La caleta de Xcaret vista desde el sitio. 


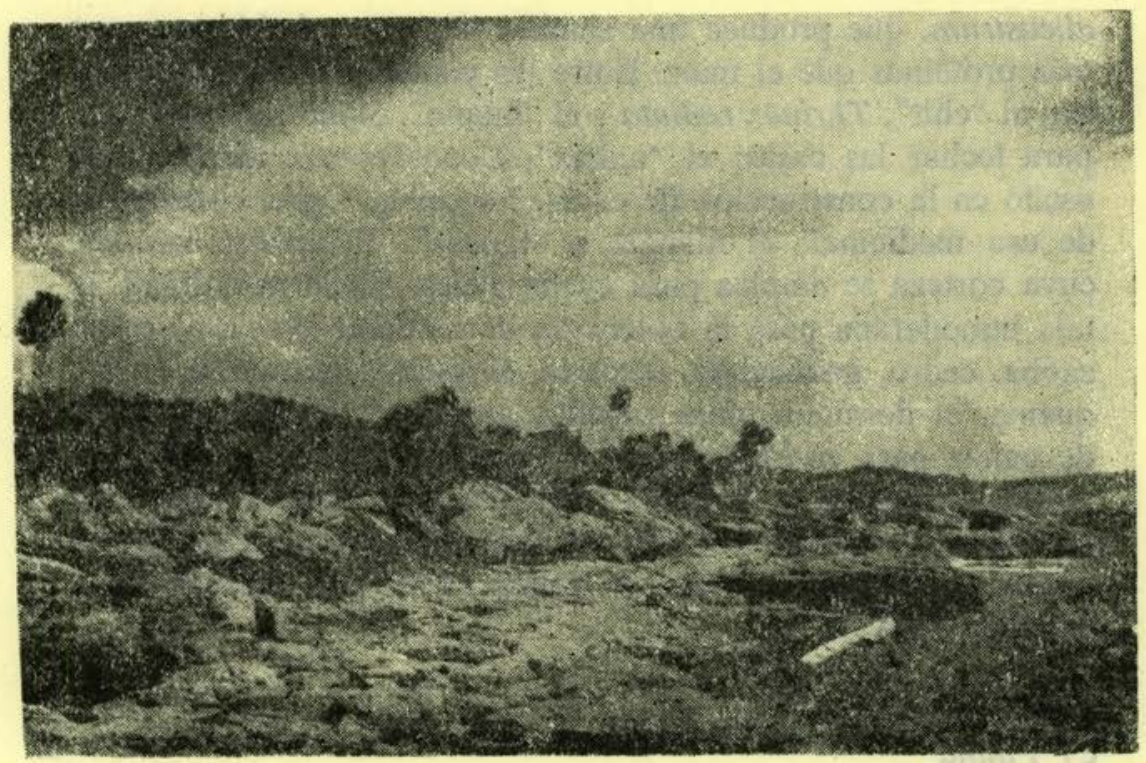

Lámina $1 \mathrm{~b}$. Vista hacia el norte de la costa rocosa. Al fondo el templo K-I.

secas va de diciembre a abril y la de lluvias de junio a octubre. Los vientos predominantes son los alisios del este-sureste, con factibilidad ciclónica de junio a noviembre.

\section{d) Flora}

La cubierta vegetal de esta región está clasificada como Selva Mediana Subperennifolia (Sousa y Téllez, 1982), aunque en realidad hay distintos tipos de vegetación en lo que a Xcaret toca. Así, tenemos zonas con altos árboles, otras más alteradas con matorrales espinosos, zonas de mangle y vegetación de duna.

De forma muy general señalaremos aquellas especies que son las más conocidas y que tuvieron y tienen aún gran utilidad (entre comillas el nombre en maya): el chicozapote, Manilkara zapota, sus duras maderas proporcionan buen material para la construcción, del látex se obtiene el chicle, y su fruto es comestible; el "chacah", Bursera simaruba; el cedro, Cedrella odorata; la caoba, Swietania macrophylla; el ramón, "oc", Brosimum 
alicastrum, que produce una semilla rica en carbohidratos con más proteínas que el maíz. Entre las palmas las más utilizadas son el "chit", Thrinax radiata y el "huano", Sabal yapa utilizada para techar las casas; el "nakax", Coccothrynax readdi, muy usado en la construcción de casas. La ceiba, Ceiba obtusifolia, de uso medicinal; el mangle o "tapche", Rizophora mangle, cuya corteza se emplea para curtir pieles. En la actualidad, la tala inmoderada para la obtención de maderas preciosas como caoba, cedro, guanacaste, etcétera, el sistema de tumba, roza y quema, el desmonte para ranchos ganaderos y la explotación de caliza para consumo local y para exportación, están afectando seriamente la cubierta vegetal y por ende el equilibrio ecológico de la región. Para una lista más completa de las especies, consúltese a Sousa y Téllez (1982) y Rzedowsky y Equihua (1987).

\section{e) Fauna}

La riqueza de especies que poblaban las selvas, manglares y costas (Pacheco Cruz, 1958), se ha visto rápidamente afectada por la acción humana. La degradación del medio ha ocasionado la disminución de algunas especies de animales silvestres, debido a que sus hábitos alimentarios y preferencias ecológicas son muy especializadas (Chávez León, 1980).

El creciente desarrollo en la costa norte y central ha ocasionado la "huida" de varias especies comunes a la zona y que antiguamente poblaban la región, a lugares menos expuestos y agresivos, tenemos entre ellas (entre comillas el nombre en maya): el faisán o "kambul", la codorniz o "bech", el pavo de monte "cutz", la perdiz "hom" y algunos patos silvestres. La tortuga "aac", el jaguar "balam", el tapir o danta "tzimin" y el manatí. Otros animales son codiciados y perseguidos por su piel, con fines gastronómicos o para su tráfico ilegal al extranjero. Así los jaguares, pumas, tucanes, tortugas, caracol, guacamayas, loros, lagartos y algunas serpientes y arácnidos son continuamente asediados. 


\section{f) Relativo a la historia del sitio}

Aunque ya Lothrop (1924: 7-24) y Andrews (1975: 4-9) han hecho amplia referencia a la historia de la costa oriental de Quintana Roo y a las investigaciones realizadas en la región, consideramos importante mencionar aunque sea brevemente algo al respecto.

Se desconoce el origen del nombre Xcaret y se piensa que pueda ser una derivación o corrupción de la palabra "caleta" (Andrews, 1975: 10; Brito Sansores, 1981). El nombre de Xcaret no aparece como tal sino hasta 1926, cuando la expedición dirigida por Gregory Mason y H. J. Spinden descubre el sitio (Mason, 1926a, 1926b, 1927, 1931, 1940).

Durante la década de los años cuarenta, L. M. Hewen visita el sitio en varias ocasiones, invitando en una de ellas a E. W. Andrews IV a hacer un recorrido por la costa. Atraído en especial por Xcaret, Andrews regresa en 1956 y explora el sitio. Entre 1972 y 1973, su hijo A. P. Andrews continúa el trabajo iniciado por su padre, dando como resultado en 1975 la publicación de un trabajo medular en lo que a la costa oriental de Quintana Roo se refiere.

Se ha dado por identificar a Xcaret con el antiguo puerto prehispánico y colonial de Polé. Esta idea fue planteada inicialmente por Loring M. Hewen (Hewen en Roys, 1957: 148) y ha sido posteriormente retomada casi como un hecho por varios autores (Chapman, 1959; Cardós de Méndez, 1959; Andrews, 1975).

Hewen, fotógrafo y explorador de la costa oriental, se basa para tal aseveración, primero, en que Xcaret es el único punto desde donde él podía ver la isla de Cozumel, segundo, en que cuenta con una caleta adecuada para albergar embarcaciones y tercero, que se trata de una zona arqueológica de importancia de donde salen antiguos caminos (sacbeoob) hacia el interior (Hewen en Roys, 1957: 148).

Polé o Ppole se deriva del término maya $P$ 'ol, que se refiere a la actividad comercial (Diccionario Maya Cordemex, 1980: 360). Brito Sansores (1981) supone que Polé se compone de la raíz p'ol que implica mercadería, el trato y contrato con mercaderes, negociación y de le, trampa o lazo. 
La referencia más temprana que se conoce hasta el momento y que hace mención a Polé, es la plasmada en un texto del Chilam Balam de Chumayel, al parecer referente a la migración de los itzá (Roys, 1957).

Encontramos otras menciones a Polé durante el siglo xvI, las primeras principalmente del paso por allí del Adelantado Montejo en 1528, y de su sobrino Montejo el Mozo en 1543 (Chamberlain, 1982: 48; 234).

Algunos documentos históricos mencionan a Polé entre 1549 y 1582, y aparece en mapas entre 1766 y 1878 . La ubicación del sitio en estas cartas varía, pero casi siempre se le sitúa en algún punto opuesto a la isla de Cozumel (Roys, 1957: 148-9; Andrews, 1975: 11). Polé fue conocido como el punto de embarque a la isla de Cozumel y principalmente como el puerto de donde salían las peregrinaciones que se dirigían al santuario de la diosa Ixchel en la misma isla.

\section{EL RECONOCIMIENTO}

\section{a) Metodología}

El recorrido y mapeo del sitio abarcó una extensión de 70 ha. Dado el tipo de vegetación y la topografía del área, fue necesario trazar una retícula con unidades de $100 \mathrm{~m}$ por lado (una hectárea cada una), a las que se les dieron números arábigos de este a oeste y letras en sentido norte-sur. La retícula fue trazada con teodolito y brechada para poder tener los puntos de referencia en campo. Cada cuadro o unidad fue recorrido en su totalidad, localizando cada elemento arquitectónico y accidentes naturales del terreno como rejolladas, cenotes, cuevas, etcétera. Se utilizó cinta métrica y brújula Brunton azimutal para registrar cada elemento, que se iba dibujando simultáneamente (Con, 1986).

Se conservó la nomenclatura dada por Andrews de letras para denominar grupos y números romanos para estructuras. Cuando se encontraron nuevas estructuras, éstas recibieron la letra del grupo más cercano y el número siguiente (fig. 3 ). 


\section{b) Extensión del sitio}

Las 70 ha. recorridas durante nuestro trabajo, nos hicieron percatarnos de la dificultad que existe para fijar los límites del sitio. Si bien la zona central o nuclear representada por grupos de estructuras asociadas es claramente definible en su conjunto, los límites del área habitacional son difíciles de establecer con los estudios hasta ahora realizados. La zona habitacional compuesta de una red de albarradas, pequeñas plataformas y cuartos, forman prácticamente un continuum a lo largo de toda la costa norte y centro. Este patrón tradicional de asentamiento se extiende en forma continua hasta donde se concce, $6 \mathrm{~km}$ tierra adentro.

También es común encontrar grupos dispersos y/o estructuras aisladas a orillas del mar. Andrews incluye algunos de éstos bajo la nomenclatura de Xcaret, 'aunque son grupos que en ocasiones distan mucho de lo que es la zona núcleo del sitio (fig. 2). Posiblemente estudios futuros puedan establecer la relación existente con los grupos nucleares de mayor tamaño e importancia.

Trabajos realizados por el INAH en el sitio de Punta Piedra a escasos $2 \mathrm{~km}$ al noroeste de Xcaret, revelaron el mismo patrón de asentamiento. Los sondeos realizados por medio de brechas hacia Xcaret demostraron un ligero descenso en el número de elementos constructivos, incrementándose éstos hacia el sitio de Xamanhá en Playa del Carmen, que es el sitio mayor a $6 \mathrm{~km}$ al norte de Xcaret (E. Terrones y L. Leira, com. verbal). Una extensa área trabajada recientemente hacia el sur de Xamanhá mostró el mismo patrón: un grupo central, con adoratorios costeros aislados, y una extensa red de albarradas y casas habitación (Silva y Hernández, 1987).

Hacia el suroeste de Xcaret además de los grupos L, M, N, O, P y Q de Andrews (1975) (fig. 2), y otros recientemente encontrados (E. Terrones y L. Leira, com. verbal), no hay interrupción en los asentamientos, según lo demuestran los recorridos recientemente realizados en el área (E. Terrones, com. verbal). El sitio mayor al sur de Xcaret como a $10 \mathrm{~km}$ de distancia es Paamul, no explorado aún. 


\section{c) Descripción de los grupos principales}

La franja costera donde se asienta la zona arqueológica de Xcaret es rocosa y sin playa (lám. 1b). Ésta se encuentra hacia el norte en Playa del Carmen, y hacia el sur en la bahía de La Ina (fig. 1). Los constructores de Xcaret escogieron precisamente este punto donde el mar rompe la costa y forma una caleta (lám. 1a), la cual brinda buena protección a embarcaciones pequeñas, $\mathrm{y}$ donde se levanta un promontorio natural de 3 a $4 \mathrm{~m}$ que proporciona una excelente protección contra inundaciones provocadas por ciclones y tormentas (fig. 3 ). Sobre este promontorio se sitúan las principales estructuras. Justamente en la parte posterior de la caleta se abre la puerta de una muralla que corresponde al acceso al sitio desde el mar. La muralla corre paralela a la costa a un lado del Grupo A, alternándose con la roca y los riscos naturales y une físicamente a las estructuras D-I, E-I, E-II y E-III (fig. 3). Esta muralla sólo se presenta del lado del mar.

Dado que Andrews en su trabajo hace una breve descripción de los grupos principales del sitio, hemos considerado importante ampliar ésta, y hacer notar los cambios que las estructuras han sufrido desde entonces, ya que la zona ha sido sistemáticamente saqueada (Con, 1986; 1987). Los principales grupos de Xcaret se distribuyen paralelos a la costa hacia el noreste, distan de ella entre 100 y $160 \mathrm{~m}$ y son nueve en total (A, B, C, D, E, F, G, H y K). De todos ellos sólo los grupos A y $\mathrm{K}$ fueron excavados y consolidados, así comó el templo superior de la estructura D-I y la muralla.

\section{Grupo A}

El grupo está conformado por diez estructuras que se encuentran en la parte posterior de la caleta y detrás de la muralla, muy cercana a su entrada (figs. 3 y 4 ). Las nueve primeras descansan sobre una plataforma, conformando una plaza. Andrews sólo reporta nueve de ellas. La décima fue encontrada por nosotros detrás de los templos A-II, A-III y A-IV a la orilla de un pequeño cenote y cerca de la esquina de donde la muralla quiebra en ángulo recto para dirigirse al mar (fig. 4). 


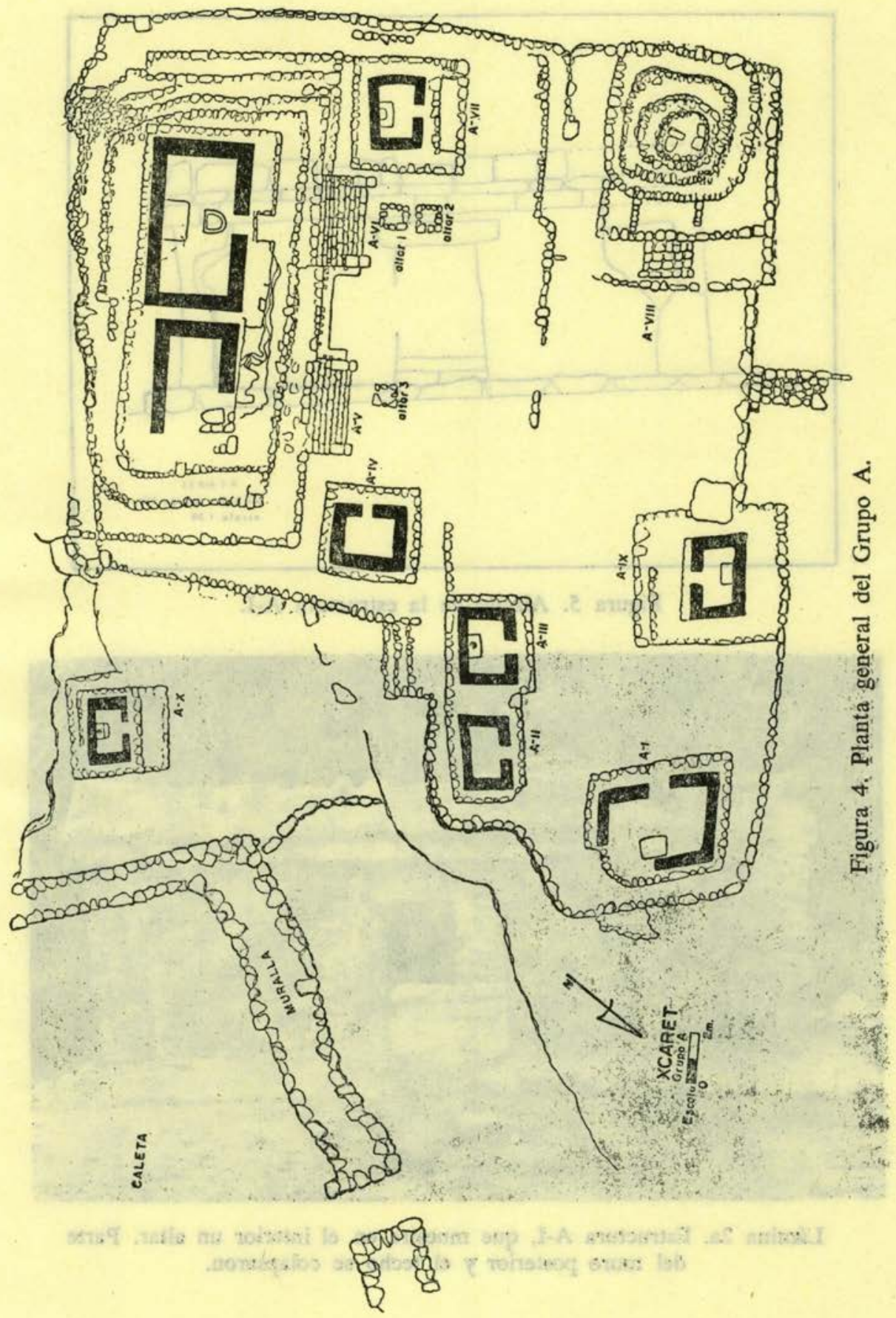




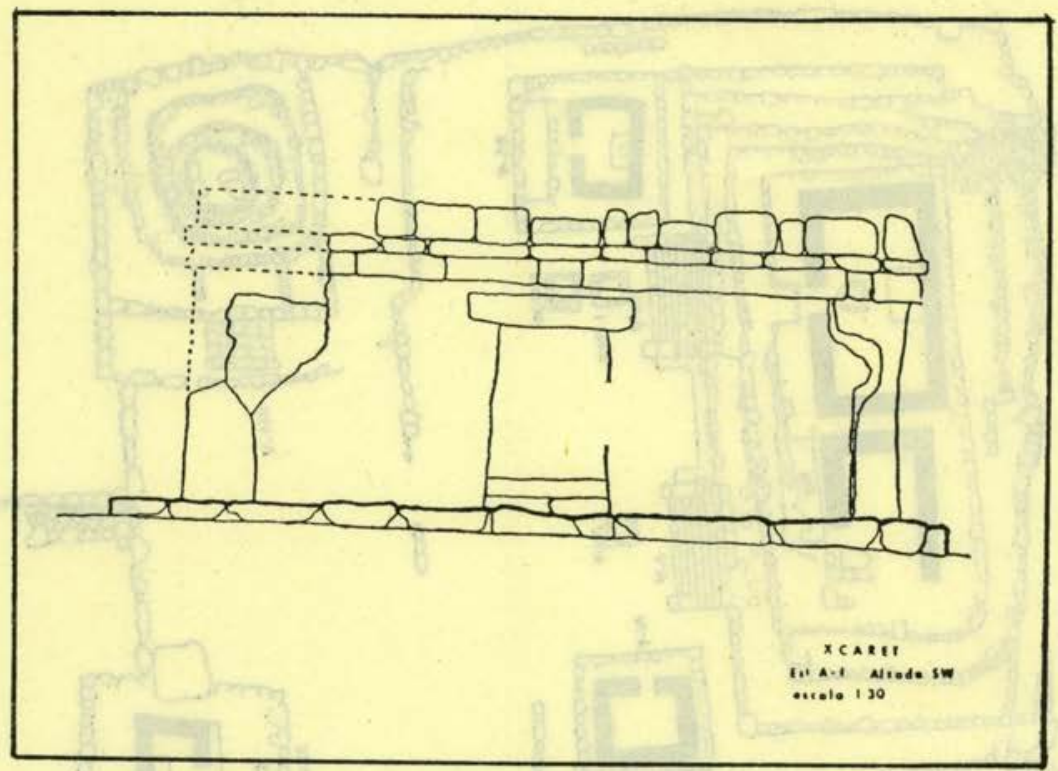

Figura 5. Alzado de la estructura A-I.

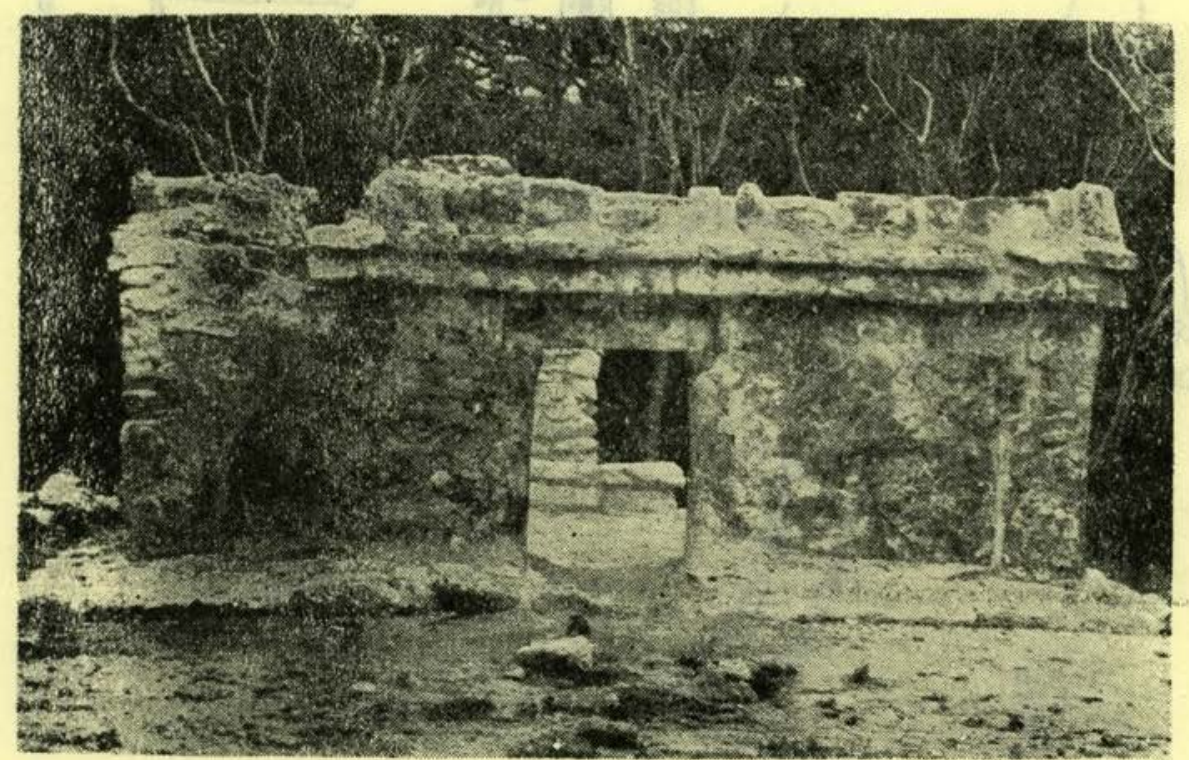

Lámina 2a. Estructura A-I, que muestra en el interior un altar. Parte del muro posterior y el techo se colapsaron. 
Estructura A-I. Descansa sobre una banqueta de planta rectangular lo mismo que el edificio (fig. 4). La puerta es de forma trapezoidal, siendo más ancha en la parte inferior que en la superior (fig. 5 ; lám. 2a). Remata en un dintel remetido de una sola pieza que presenta bandas verticales alternando el azul y el rojo. Enmarcando la puerta y el dintel dos bandas de los mismos colores la adornan. Sobre la fachada a ambos lados de la puerta, como a $60 \mathrm{~cm}$ sólo quedan las huellas de dos guacamayas en estuco que Andrews reporta (Andrews: 1975: 18f; $83 a)$. El edificio presentaba una moldura conformada por tres elementos que solamente se aprecia sobre el dintel.

El techo, a diferencia de los demás de este grupo era plano, hecho con morillos en sentido longitudinal al edificio, los que descansaban sobre cinco gruesas vigas, colocadas transversalmente y cuyo diámetro variaba entre 13 y $21 \mathrm{~cm}$ (lám. 3a). Sobre los morillos colocaron otra capa de troncos más delgados que recubrieron con una gruesa capa de argamasa (lám. 2b). $\mathrm{Al}$ interior, el edificio presentaba un altar muy destruido lo que impidió saber si había sido saqueado o no. Dentro del altar se

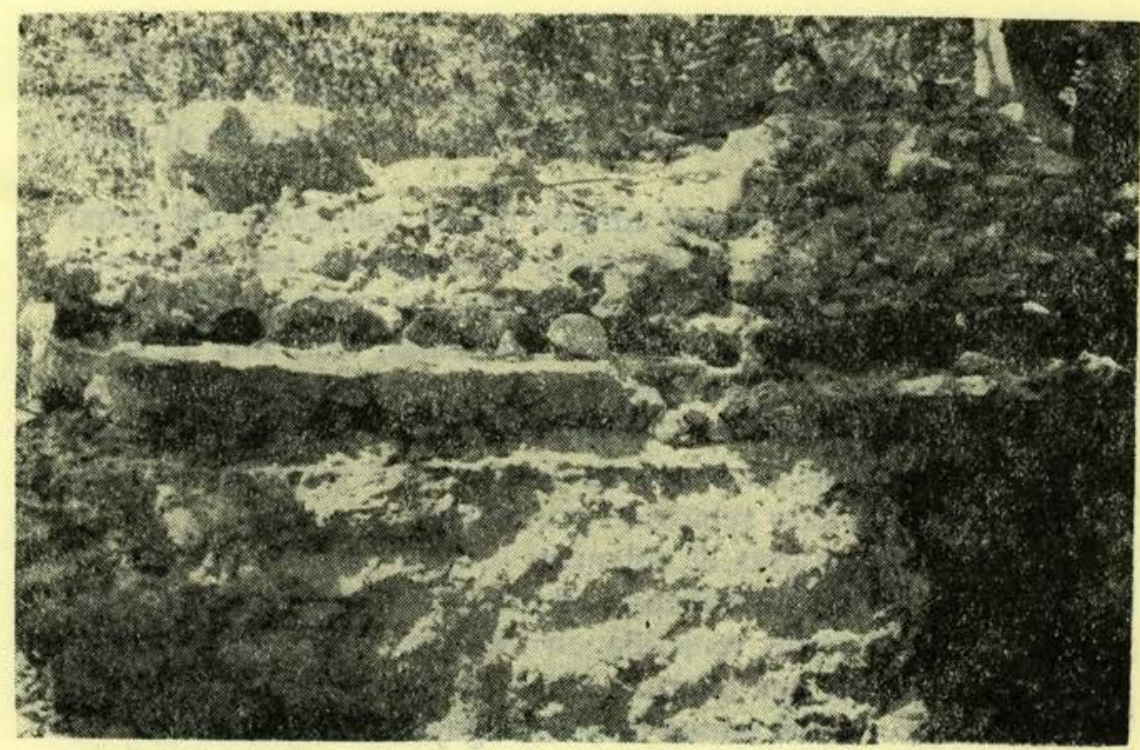

Lámina $2 b$. Huellas de la forma en que se construyó el techo plano de la estructura A-I. 


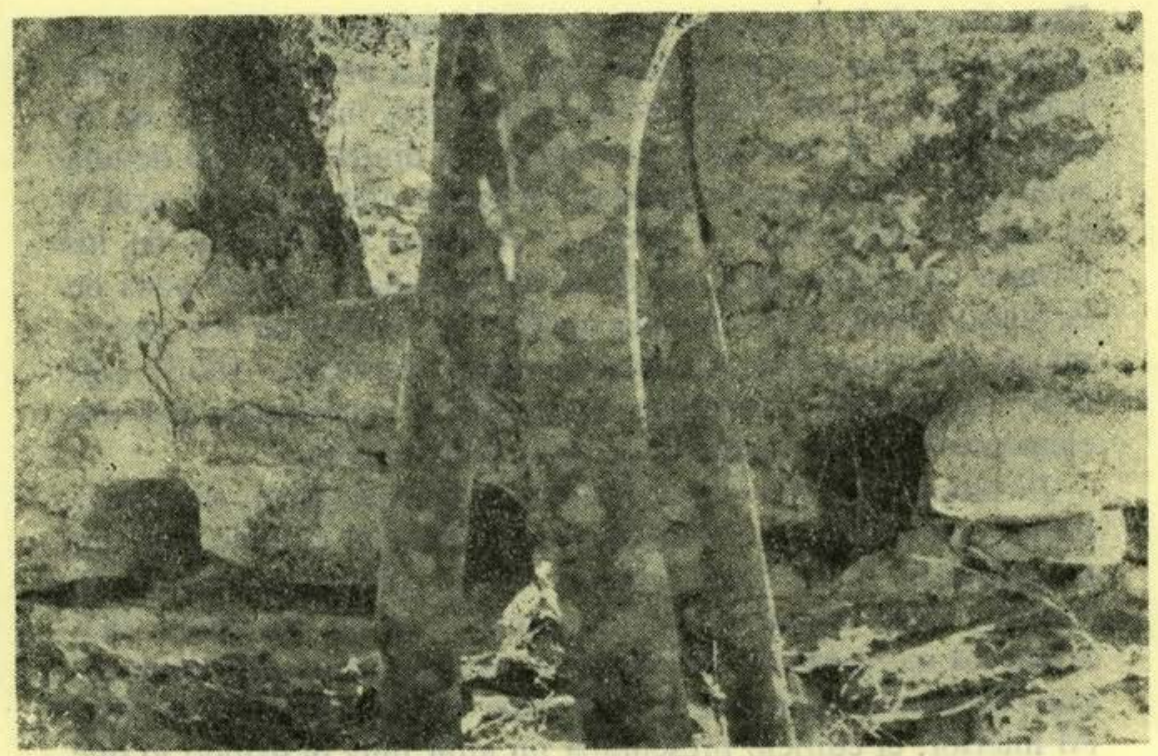

Lámina 3a. Parte interior de la fachada de la estructura A-I. Se aprecia el lugar donde se insertaron las vigas del techo.

encontró un pequeño cono de cerámica que contenía una navajilla de obsidiana gris, y una cuenta cilíndrica de piedra verde. El piso de estuco en el interior de la estructura recubría al altar.

Estructura A-II. Este es el edificio mejor conservado del grupo ya que está completo. Es de planta rectangular y está sobre una banqueta de una sola hilada de piedras, la cual comparte con la Estructura A-III. Al igual que los demás, tiene una moldura de tres elementos, dintel remetido de una sola pieza y techo de bóveda. Andrews (1975: 17) señala la existencia de un pequeño altar en su interior, del cual no encontramos huella ni indicios de que hubiera sido removido por saqueo.

El edificio conserva el aplanado original en casi toda su fachada. La parte sobresaliente del dintel muestra restos de pintura roja. La parte remetida en cambio, tiene siete bandas verticales, en lás que alternan los colores rojo y azul. Presenta en cada uno de los muros laterales agujeros de ventilación. El edificio está inclinado hacia uno de sus lados, debido al deslizamiento que sufrió la plataforma sobre la que descansa, y la 


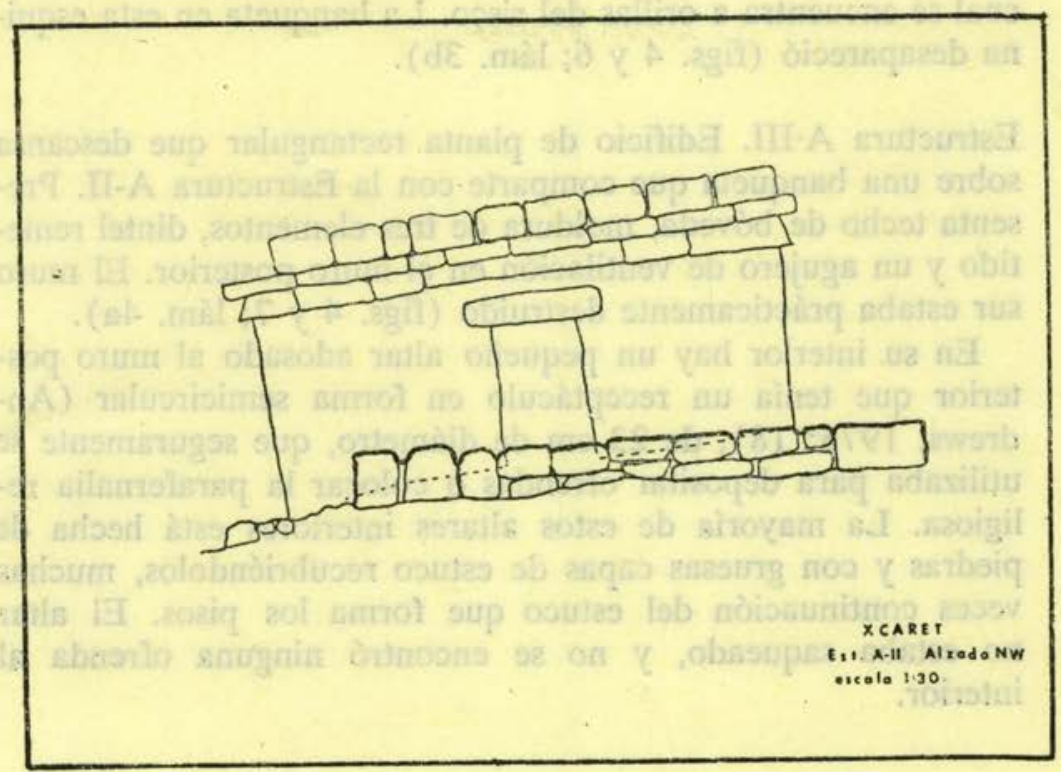

Figura 6. Alzado de la estructura A-II.

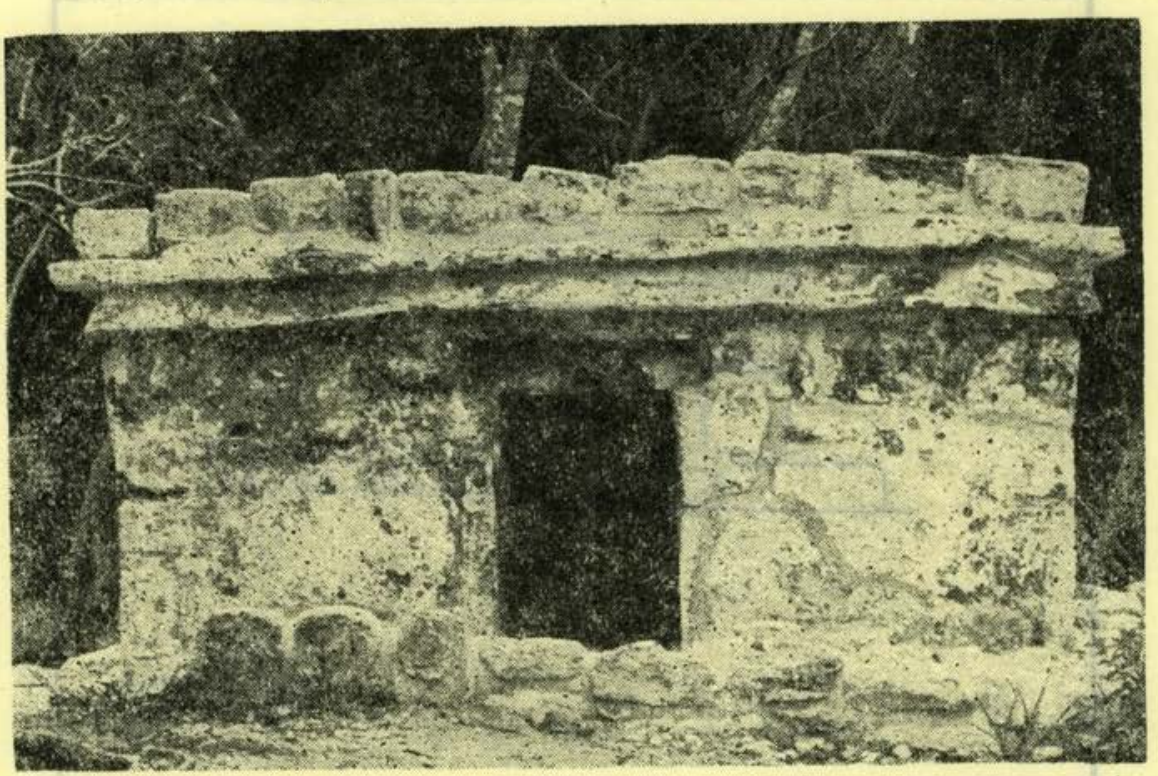

Lámina 3b. Estructura A-II después de la consolidación, todavía muestra restos de pintura roja en su fachada. 
cual se encuentra a orillas del risco. La banqueta en esta esquina desapareció (figs. 4 y 6; lám. 3b).

Estructura A-III. Edificio de planta rectangular que descansa sobre una banqueta que comparte con la Estructura A-II. Presenta techo de bóveda, moldura de tres elementos, dintel remetido y un agujero de ventilación en el muro posterior. El muro sur estaba prácticamente destruido (figs. 4 y 7; lám. 4a).

En su interior hay un pequeño altar adosado al muro posterior que tenía un receptáculo en forma semicircular (Andrews, 1975: 18), de $23 \mathrm{~cm}$ de diámetro, que seguramente se utilizaba para depositar ofrendas o colocar la parafernalia religiosa. La mayoría de estos altares interiores está hecha de piedras y con gruesas capas de estuco recubriéndolos, muchas veces continuación del estuco que forma los pisos. El altar no estaba saqueado, y no se encontró ninguna ofrenda al interior.

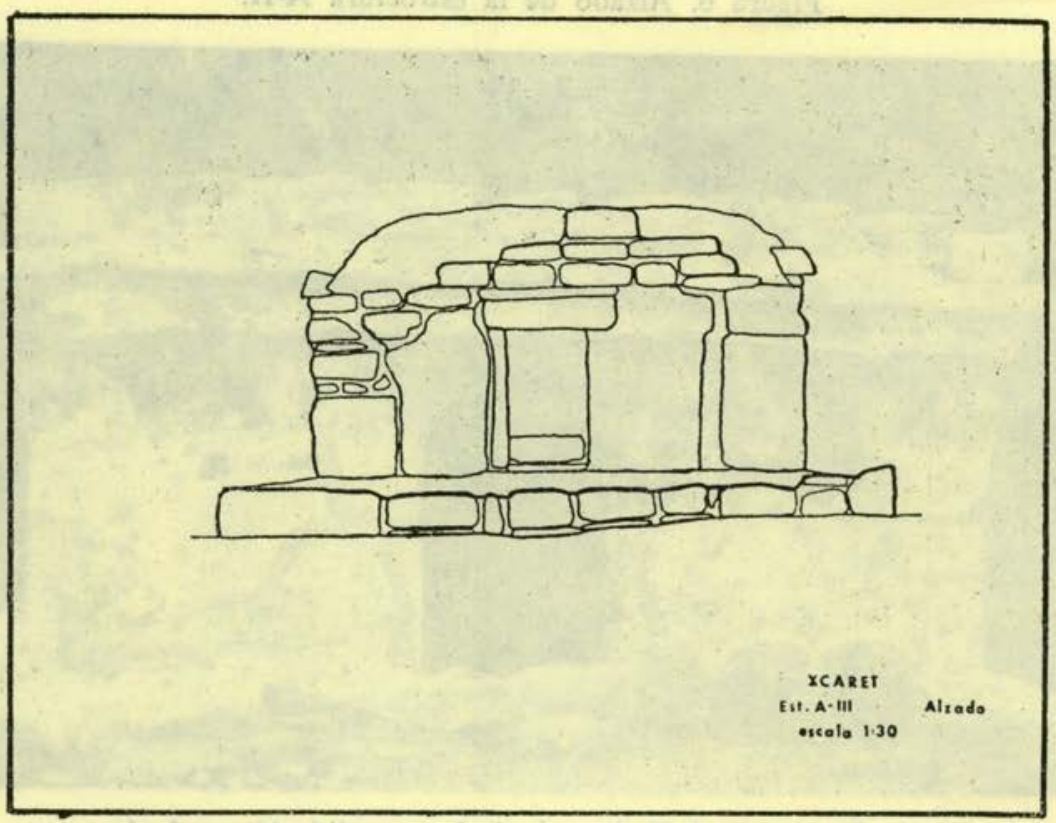

Figura 7. Alzado de la estructura A-III. 


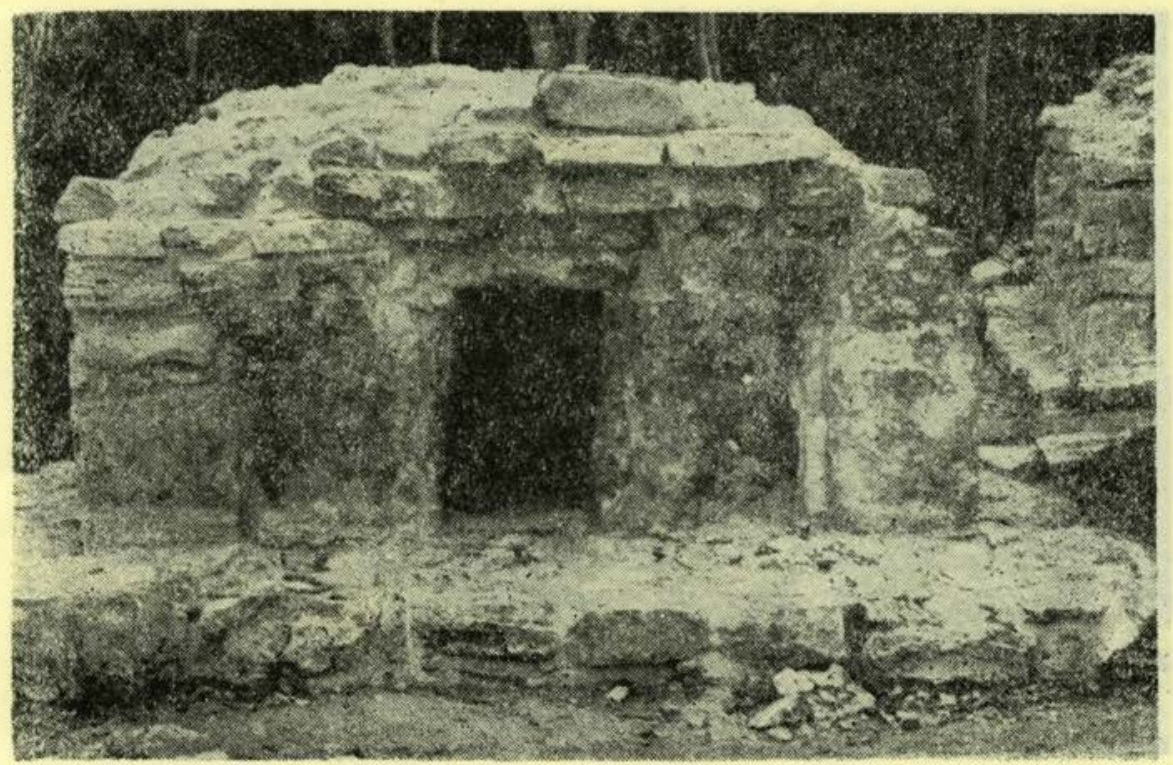

Lámina 4a. Estructura A-III, detrás de la cual llega uno de los accesos a la plaza.

Estructura A-IV. Edificio de planta rectangular y techo abovedado. Por la disposición y los restos de molduras encontrados, podemos decir que ésta era de tres elementos. Una característica peculiar de este edificio es que el dintel junto con la pieza que limita con elemento de la moldura son de una sola pieza, por lo que para lograr el efecto de remetimiento del dintel, se talló en la misma pieza. Este edificio se encontró muy deteriorado, ya que el muro posterior y la bóveda se habían colapsado por el peso de un árbol que cayó encima. No presenta altar en su interior; sin embargo, en el piso, bajo el vano de la puerta, se encontró una protuberancia hecha con estuco que servía para evitar la entrada del agua al interior del templo (figs. 4 y 8 ; lám. 4b).

Estructura A-V, VI. Es el único edificio en todo el sitio que presenta dos templos en su parte superior (figs. 4, 9, 10, 11; láms. $7 \mathrm{a}, 7 \mathrm{~b}$ ) y fue hallado prácticamente en el mismo estado en que Andrews lo describiera años atrás. 


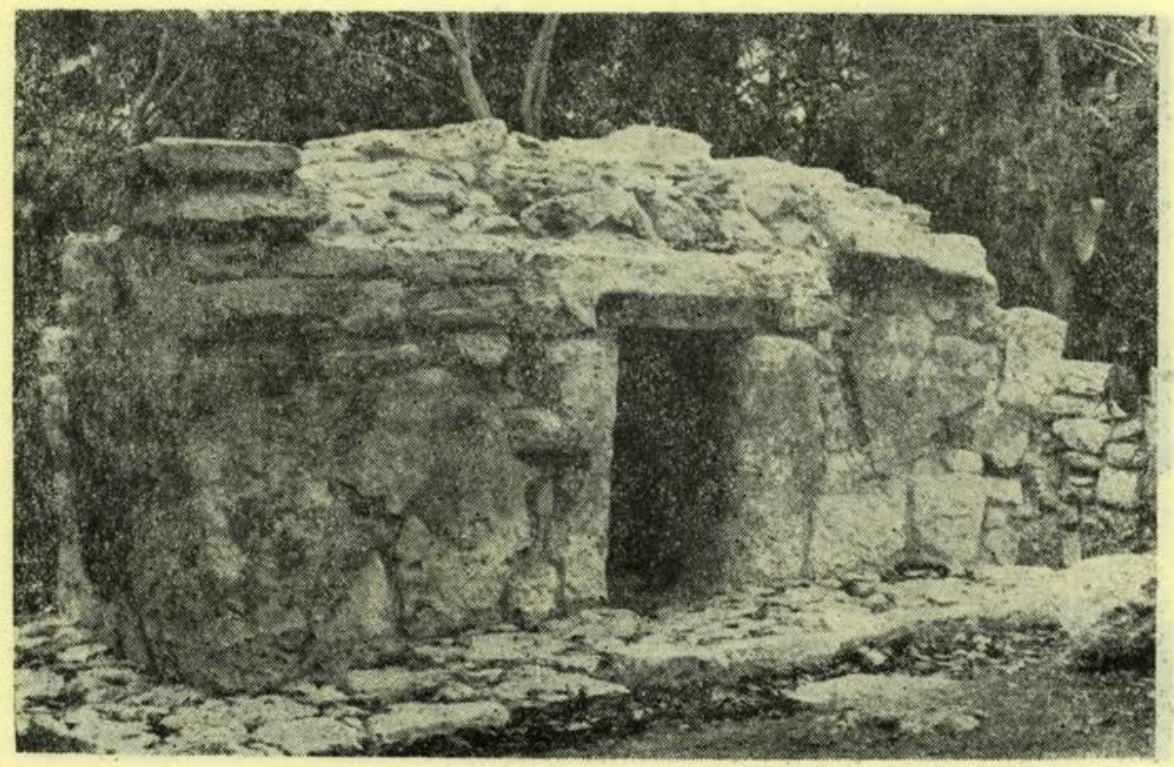

Lámina 4b. Estructura A-IV, toda su parte superior debió de ser reconstruida.

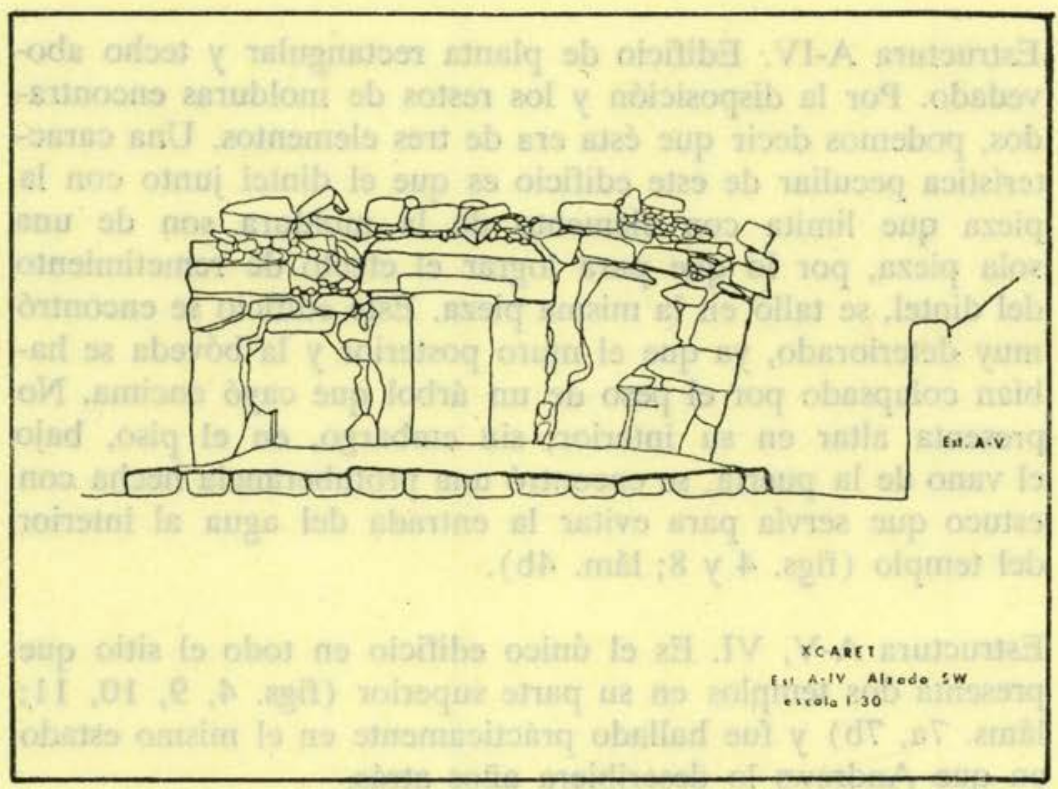

Figura 8. Alzado de la estruetura A-IV. 


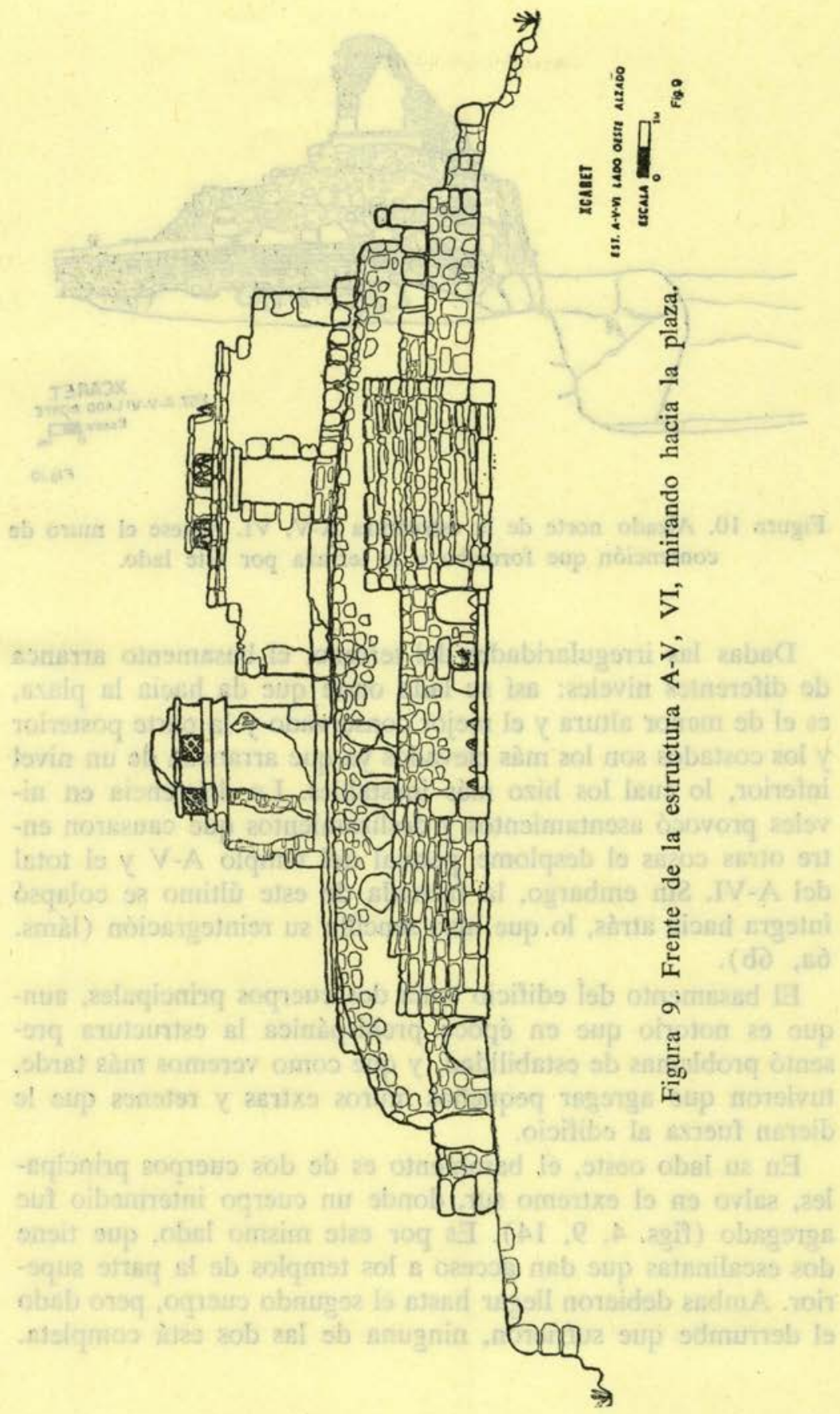

Estudios de Cultura Maya. Vol. XVIII, 1991

Instituto de Investigaciones Filológicas/

Centro de Estudios Mayas, UNAM

ISSN 0185-2574 


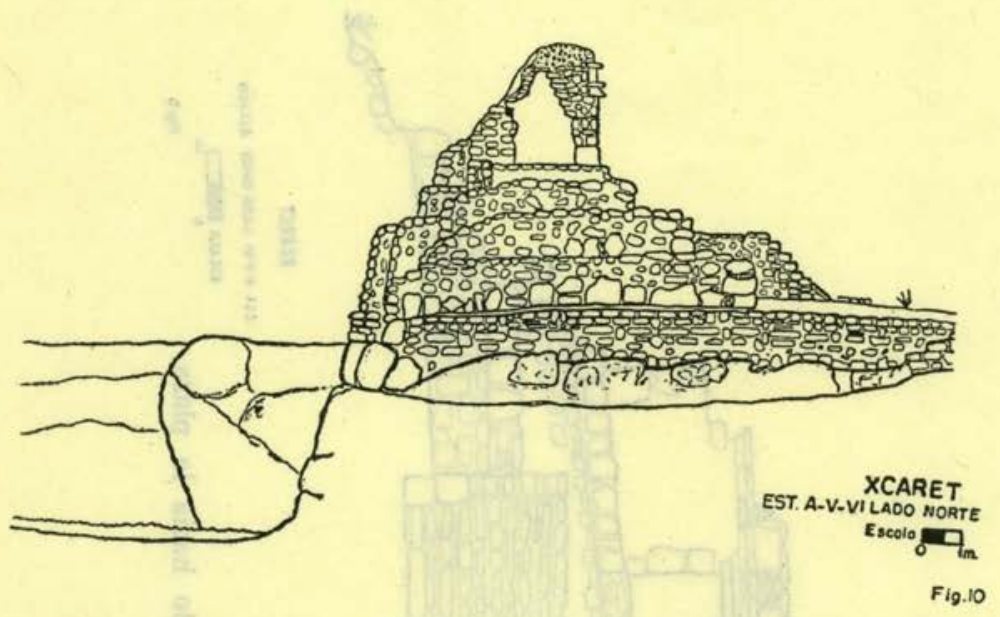

Figura 10. Alzado norte de la estructura A-V, VI. Nótese el muro de contención que formaba a la terraza por este lado.

Dadas las irregularidades del terreno, el basamento arranca de diferentes niveles: así su lado oeste que da hacia la plaza, es el de menor altura y el mejor conservado y la parte posterior y los costados son los más elevados ya que arrancan de un nivel inferior, lo cual los hizo más inestables. La diferencia en niveles provocó asentamientos y deslizamientos que causaron entre otras cosas el desplome parcial del templo A-V y el total del A-VI. Sin embargo, la fachada de este último se colapsó íntegra hacia atrás, lo que hizo sencilla su reintegración (láms. $6 a, 6 b)$.

El basamento del edificio tenía dos cuerpos principales, aunque es notorio que en época prehispánica la estructura presentó problemas de estabilidad, y que como veremos más tarde, tuvieron que agregar pequeños muros extras y retenes que le dieran fuerza al edificio.

En su lado oeste, el basamento es de dos cuerpos principales, salvo en el extremo sur, donde un cuerpo intermedio fue agregado (figs. 4, 9, 14). Es por este mismo lado, que tiene dos escalinatas que dan acceso a los templos de la parte superior. Ambas debieron llegar hasta el segundo cuerpo, pero dado el derrumbe que sufrieron, ninguna de las dos está completa. 


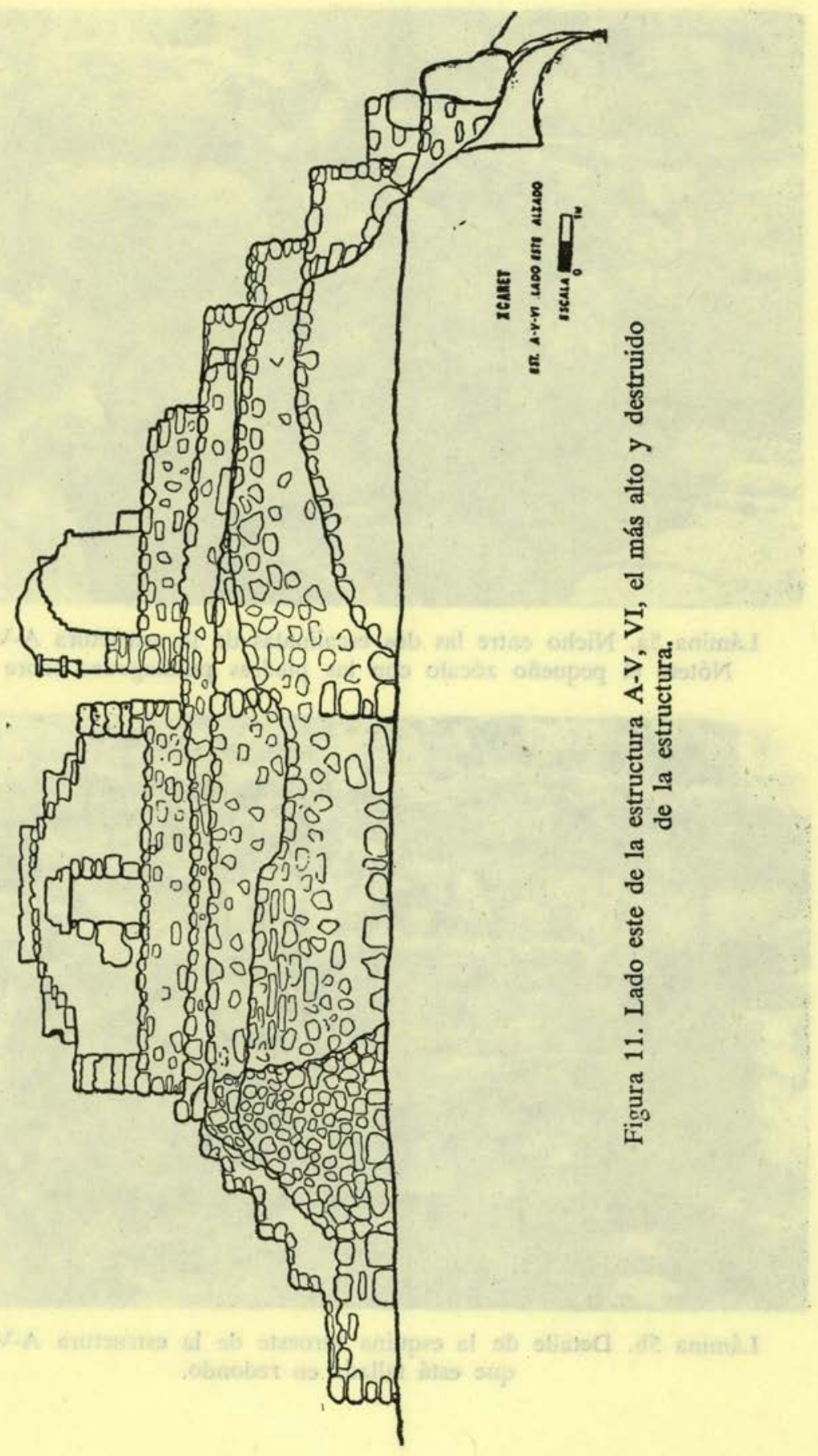




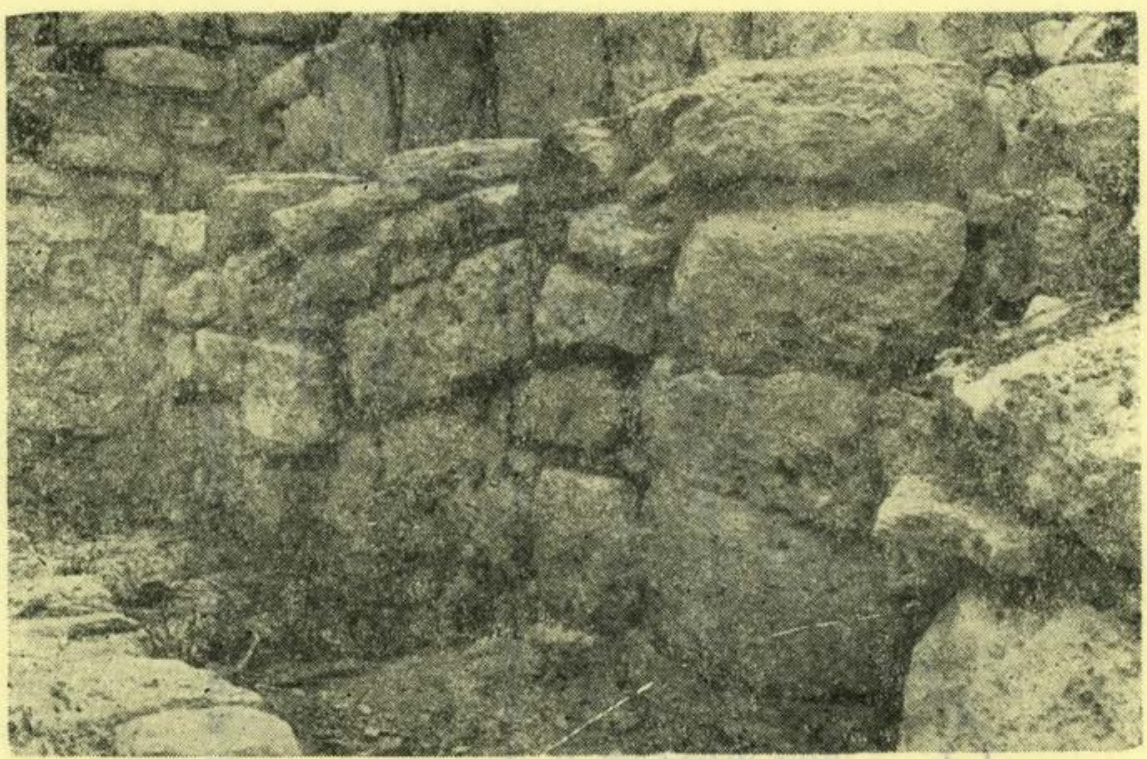

Lámina-5a. Nicho entre las dos escalinatas de la estructura A-V, VI. Nótese el pequeño zócalo con las piedras puntiagudas sobre él.

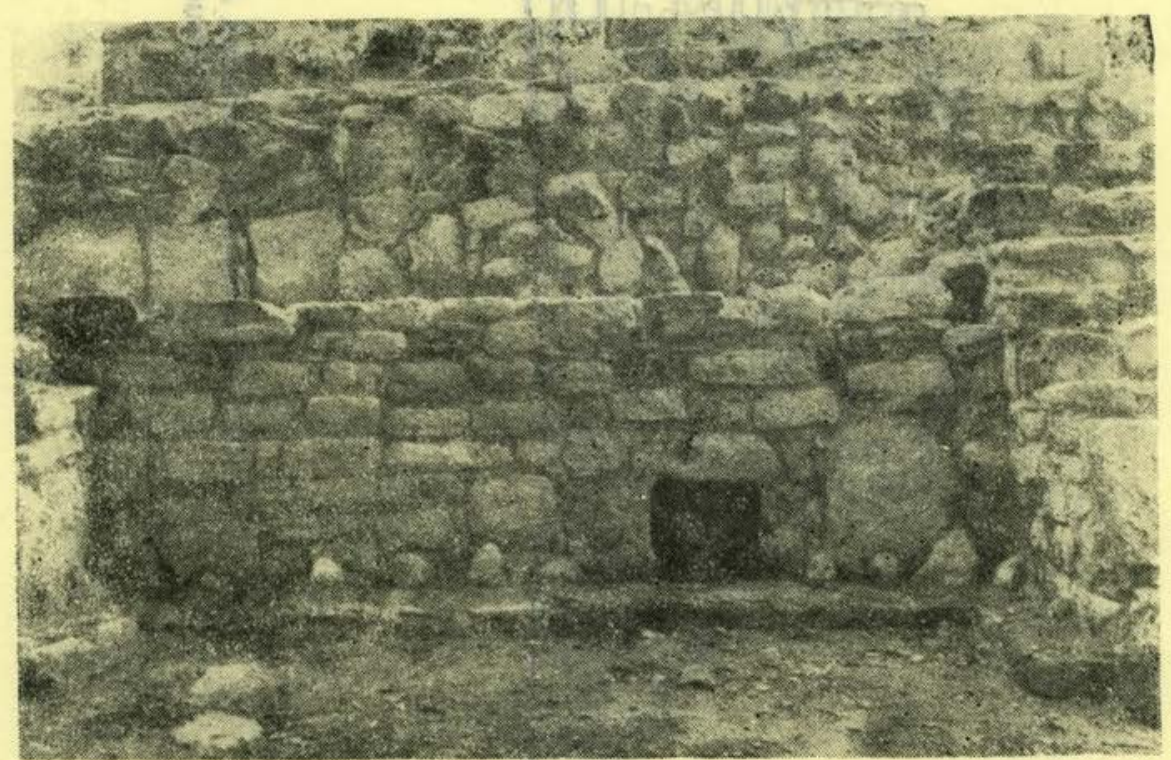

Lámina 5b. Detalle de la esquina suroeste de la estructura A-V, VI, que está tallada en redondo. 
No se trata de escalinatas superpuestas sino que forman parte integral del edificio.

Las escalinatas tenían unas alfardas de manufactura bastante rudimentaria, que consistía en colocar delgadas lajas de caliza trabajada sobre los escalones mismos, que después recubrían con una gruesa capa de estuco.

Los escalones son bloques de caliza bien trabajados y cada hilera tiene entre cinco y seis bloques, sobre los cuales colocaban piedras más pequeñas y alargadas para proporcionarle más altura al escalón. Tanto la huella como el peralte tienen un promedio entre 25 y $30 \mathrm{~cm}$. En ambas escalinatas, el primer escalón se encontró cubierto bajo el último piso de estuco de la plaza.

Entre las dos escalinatas, al nivel del primer cuerpo, se encontraron dos elementos importantes: un nicho y una especie de banqueta angosta que corre a nivel del piso y adosada a los paramentos interiores de las escalinatas y al muro donde se encuentrá el nicho. La banqueta estaba recubiertâ de una grue-

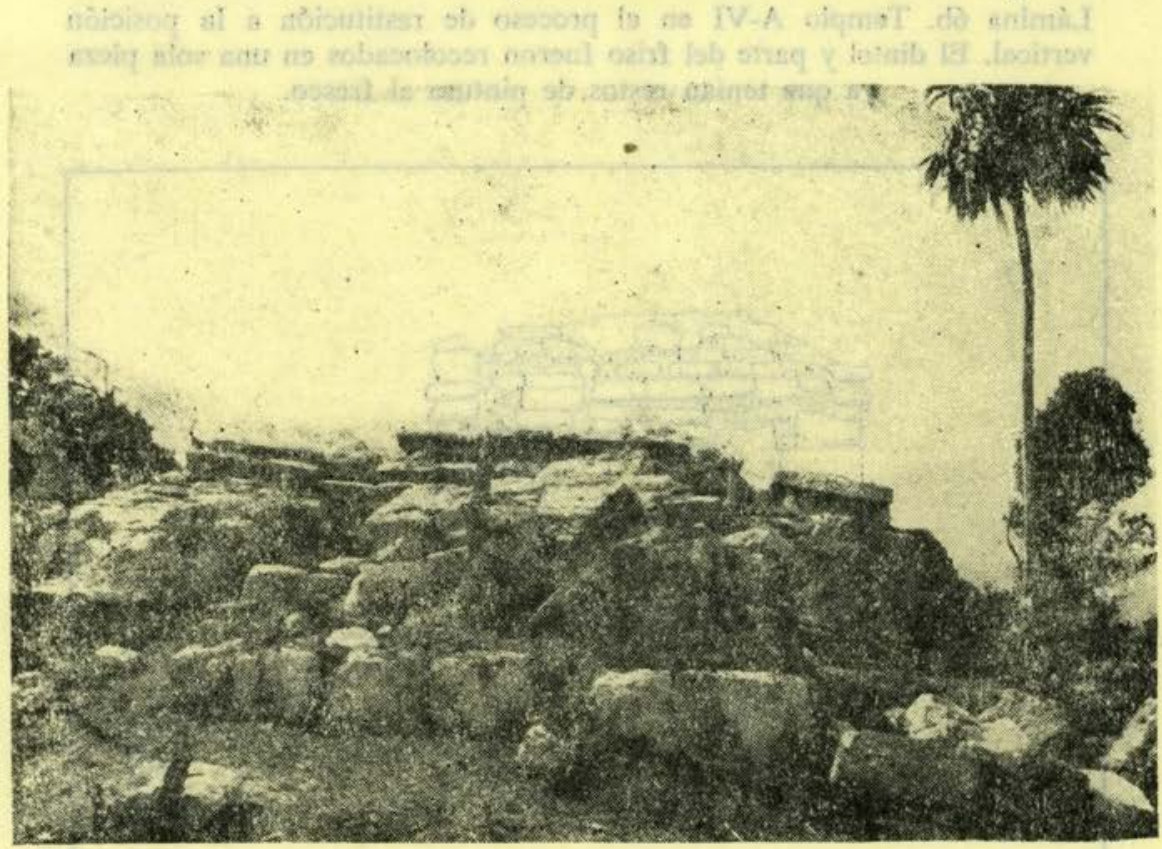

Lámina 6a. Fachada del templo A-VI, tal como se encontró, desplomada hacia atrás. 


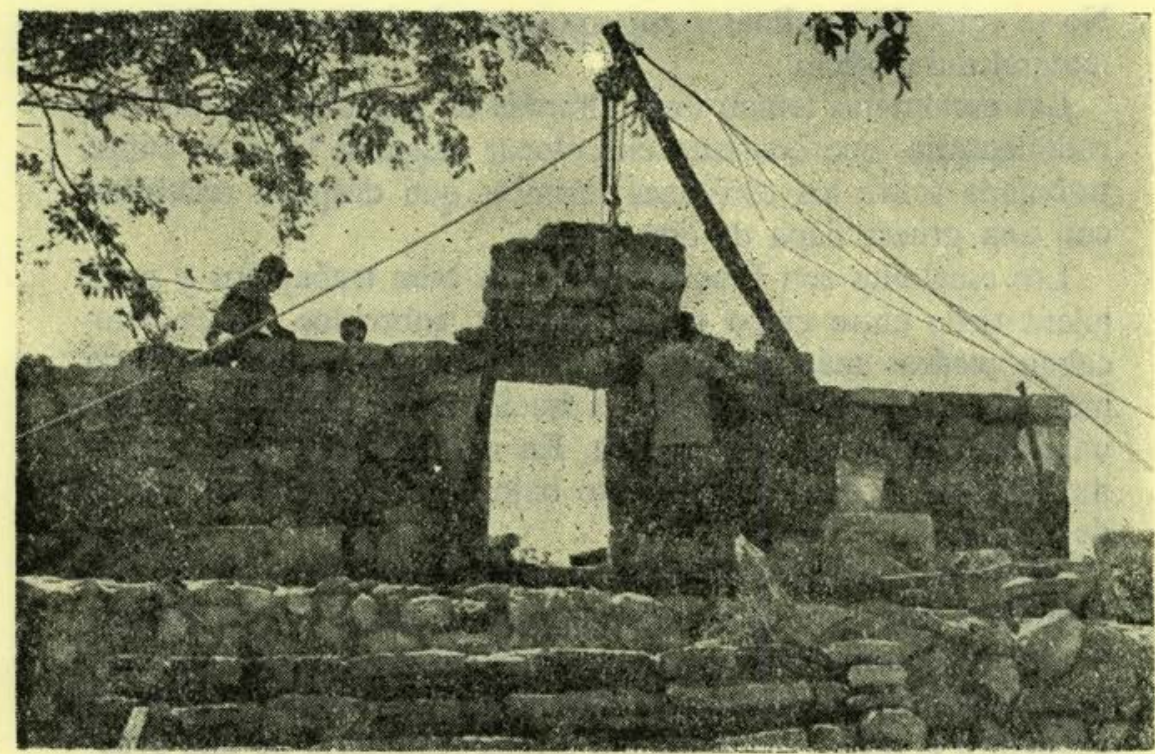

Lámina 6b. Templo A-VI en el proceso de restitución a la posición vertical. El dintel y parte del friso fueron recolocados en una sola pieza ya que tenían restos de pintura al fresco.

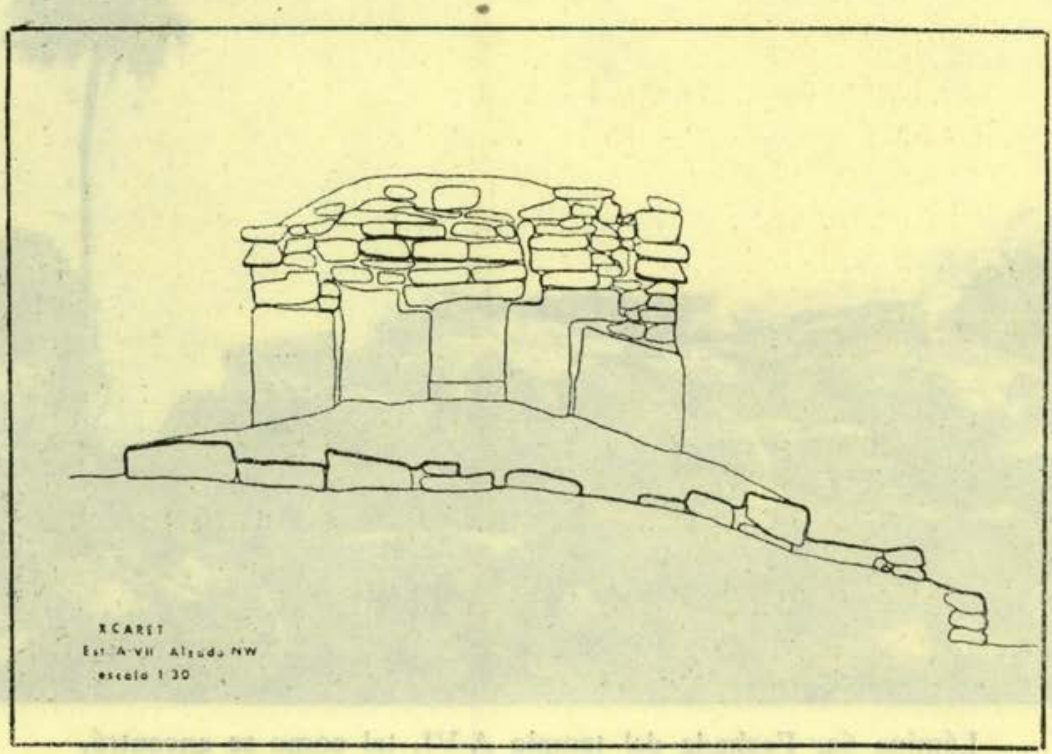

Figura 12. Frente de la estructura A-VII. 
sa capa de estuco y tiene incrustadas en ella, a intervalos más o menos regulares, piedras puntiagudas. Desconocemos su función, pero tal vez sirvieran para sostener algún adorno de estuco que rematara en la banqueta (fig. 9; lám. 5a).

El nicho no está centrado, presentaba varios recubrimientos de estuco muy sólidos y bien conservados, que le daban forma redondeada en el interior. No se encontró ninguna ofrenda.

La forma redonda de las esquinas en el basamento era lograda mediante el tallado de las piedras que las conformaban (lám. 5b). El lado sur del basamento (figs. 4, 14) claramente muestra los dos cuerpos principales (salvo hacia su esquina sureste debido al derrumbe), más uno tercero que es la continuación del intermedio, que también se presenta en el lado oeste.

Además muestra dos agregados en forma de muros de contención, uno de los cuales tenía la esquina redonda y seguramente cubrió al primer cuerpo del basamento. El segundo posiblemente llegó hasta la banqueta superior que sostiene al templo A-VI.

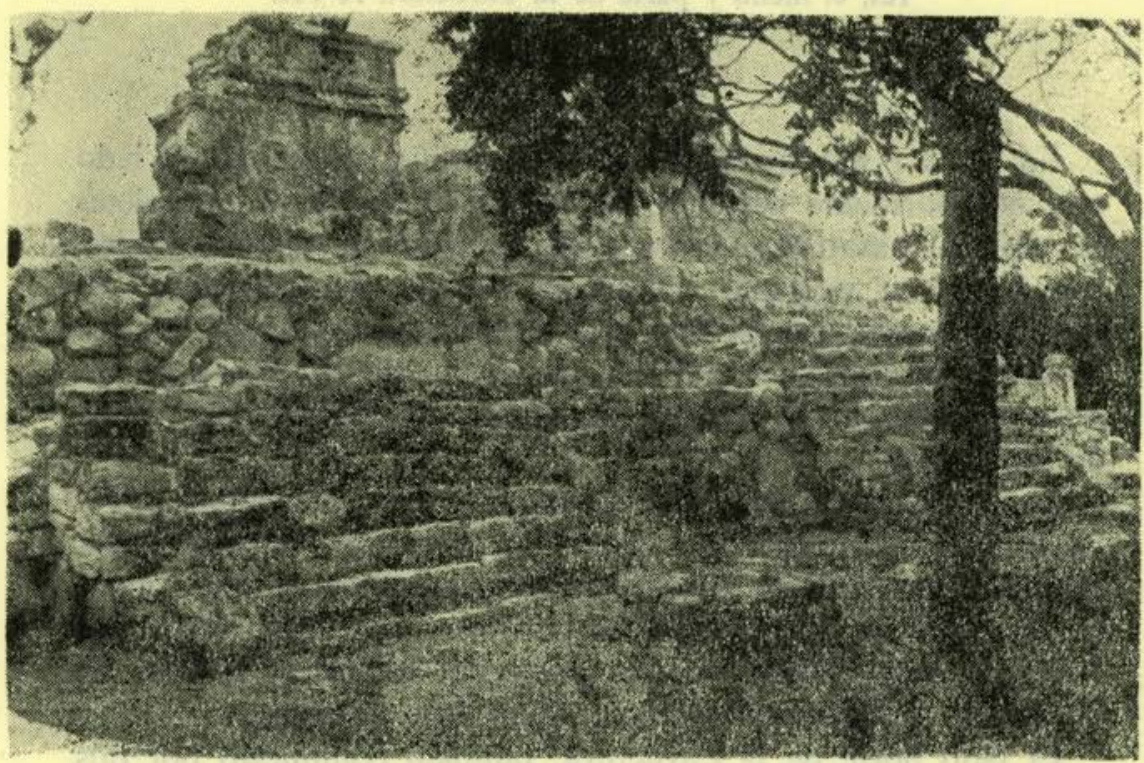

Lámina 7a. Vista de la estructura A-V, VI, desde el norte; en primer plano el altar al pie de la escalinata. 


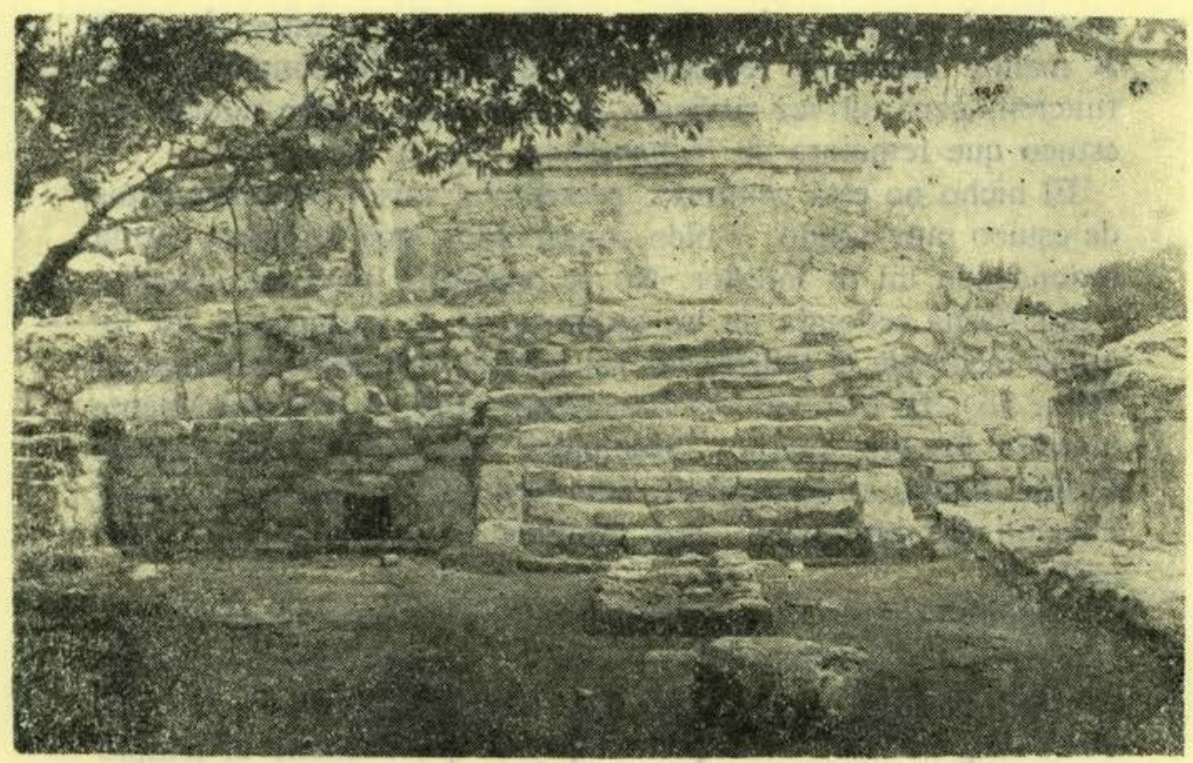

Lámina 7b. Frente de la estructura A-V, VI, se aprecian los dos altares, el nicho y parte de la estructura A-VII.

La parte posterior del edificio (fig. 11), junto con el lado sur, anteriormente descrito, fue la que se encontró más deteriorada. El basamento arranca directamente de la roca madre, que forma un pequeño acantilado natural. Aunque difícil de advertir, parece que se trata de los mismos dos cuerpos, tal vez con algunos agregados. $\mathrm{El}$ abombamiento de los muros por el peso del edificio no permite distinguir con claridad los paños de los muros.

Casi a la altura del paño del muro norte del Templo A-VI, en la base del edificio, se aprecia un muro que se mete hacia el oeste y que tenía la esquina redondeada, lo que posiblemente nos habla de una primera plataforma que sostuvo al templo A-V. La inestabilidad en esta parte del edificio y la falta de tiempo no permitieron la exploración de este elemento.

El lado norte de la estructura, también compuesto por dos cuerpos (figs. 4,10 ), descansa sobre un gran muro de contención realizado con piedras muy bien trabajadas y que le 


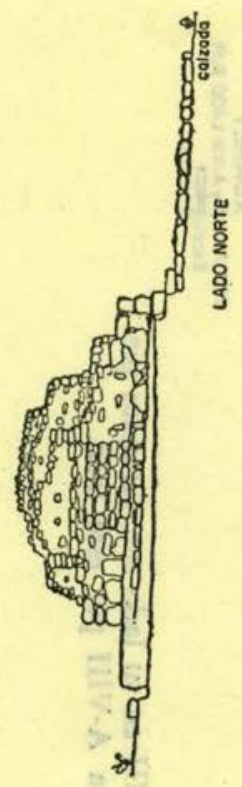

त्ञ 


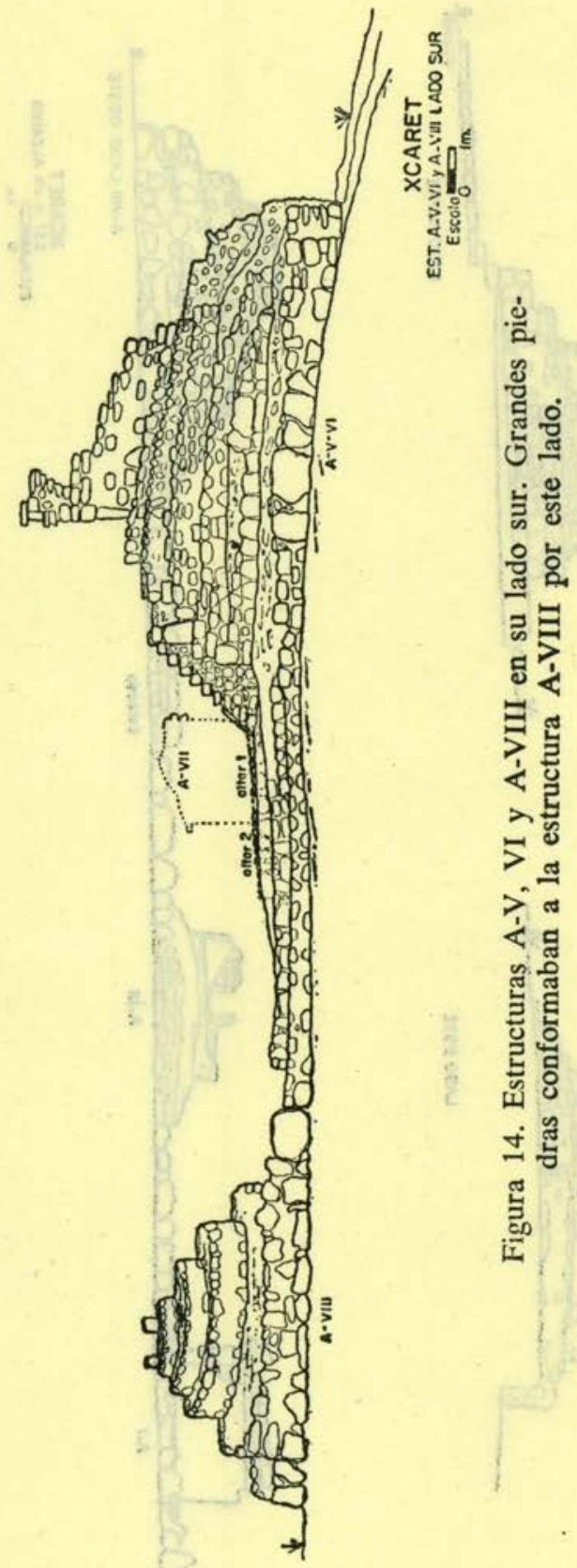




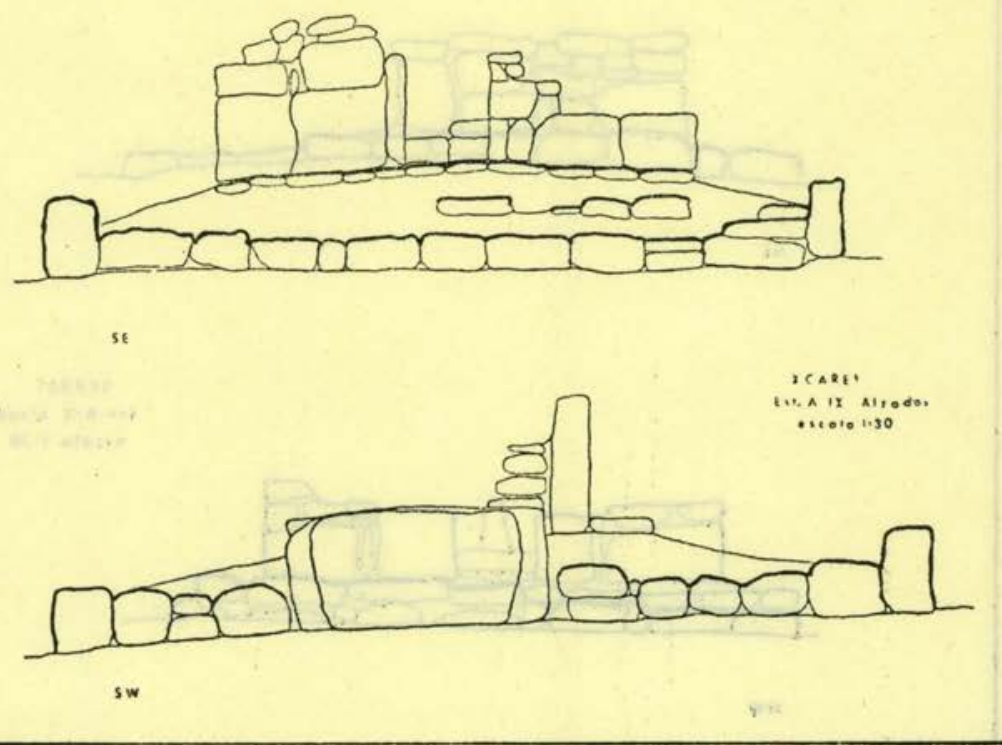

Figura 15. Estructura A-IX, una de las más destruidas del Grupo A.

daba estabilidad y el nivel requerido para alcanzar la plaza, ya que en este punto baja considerablemente el nivel del risco.

El templo A-V sólo conserva en pie parte de los muros sur y oeste, y en el ángulo que forman, sustentan un fragmento de bóveda. Lo que queda de la fachada del templo conserva una buena parte del estuco original en sus muros (figs. 4, 9, 10, 11). Todo el templo descansa sobre un estrecho zócalo, a diferencia del A-VI, que tiene una banqueta al frente, la cual en parte cubre al zócalo del A-V (fig. 4).

El muro sur tenía un agujero de ventilación, y el oeste conserva las huellas de donde iba colocada la viga de madera de la bóveda. El interior del cuarto tenía un pozo de saqueo. La decoración del templo consta de una moldura de dos elementos: medio y superior. Entre las molduras se forma un friso que presenta una serie de paneles con diseño de celosía, de los 


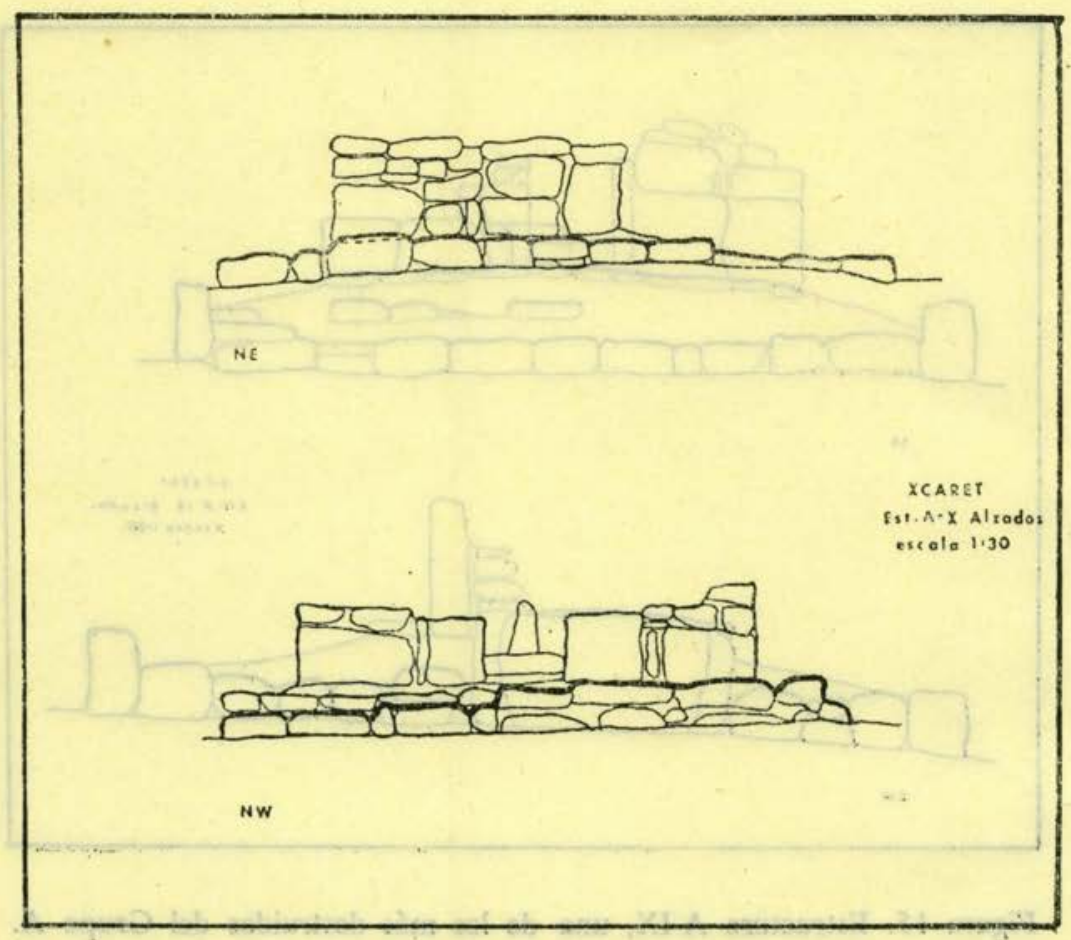

Figura 16. Alzados de la estructura A-X, cuya estalagmita se puede apreciar en el dibujo inferior.

cuales sólo quedan in situ dos de ellos. Estas celosías están hechas a base de cruces de piedra talladas individualmente $\hat{y}$ posteriormente estucadas. Este diseño es similar a las encontradas en la Estructura 21 de Tulum y a las de Punta San Juan (Andrews, 1975: 64).

La fachada del templo A-VI fue reincorporada a la posición vertical, ya que ésta se encontraba desplomada hacia atrás (figs. 6a, 6b). Descansa sobre una banqueta estucada de una sola hilada de piedras en tres de sus lados, haciéndose más ancha hacia el frente, donde se abre para dar acceso al templo. Las medidas interiores del cuarto lo hacen uno de los más grandes de Xcaret. Parte del derrumbe del techo abovedado se encontró colapsado en el interior del cuarto. 


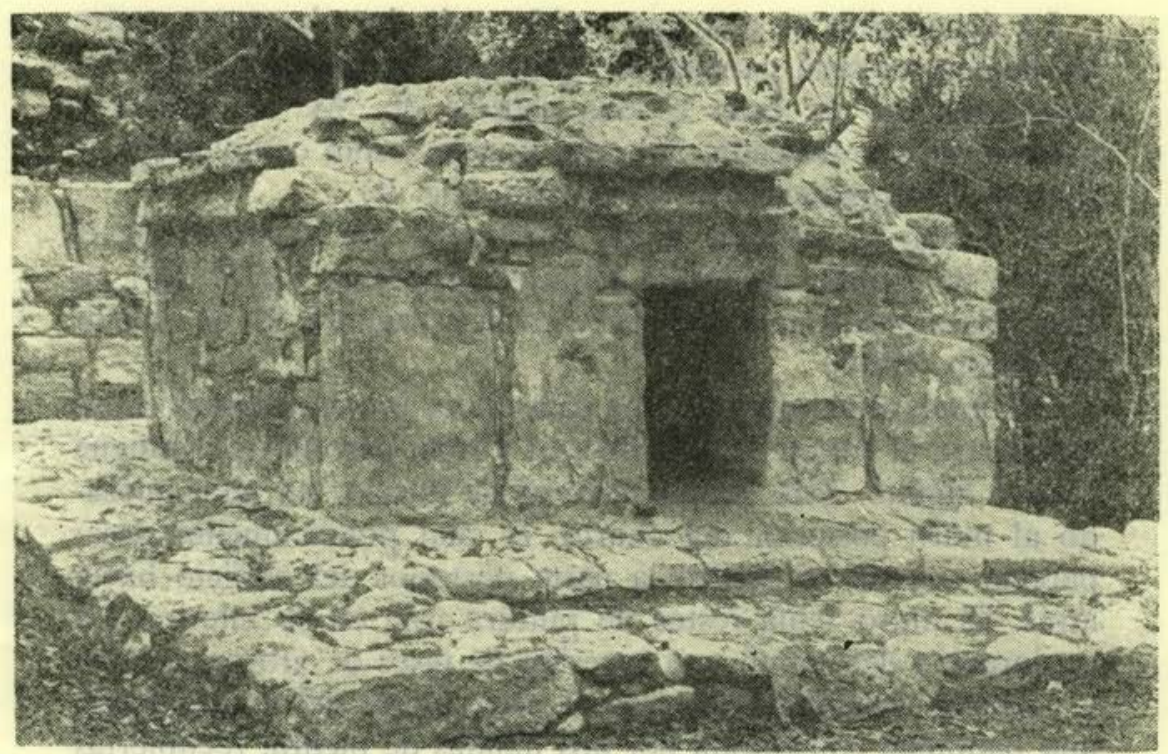

Lámina 8a. Vista de la estructura A-VII, su altar se encontraba saqueado.

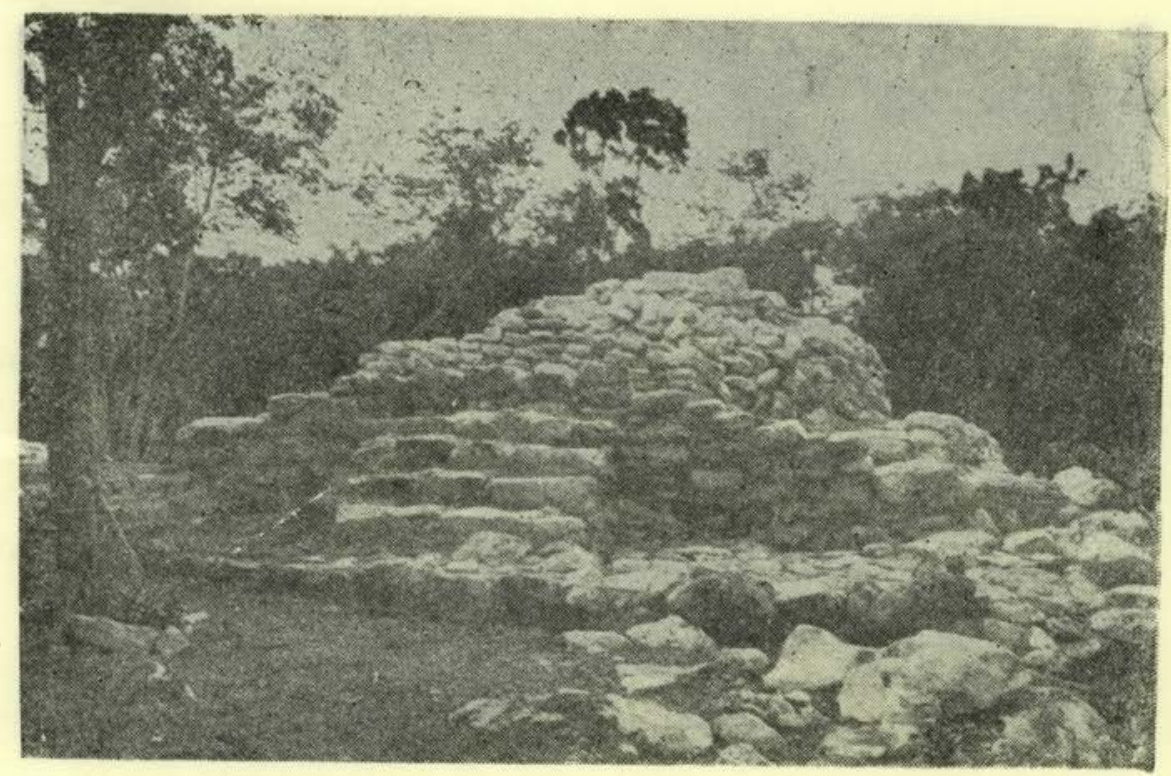

Lámina 8b. Estructura A-VIII, llamada El Caracol por ser redonda. 
La decoración es con una moldura de dos elementos, entre los cuales presenta paneles, al igual que el templo vecino. La representación de éstos es una especie de " $M$ " de piedra y posteriormente estucada. Sólo dos paneles están completos y se conserva el fragmento de un tercero (fig. 9).

El diseño se asemeja a los reportados por Andrews en el templo de Nohku en Punta Pájaros (Andrews, 1975: 64) en Kiic (Escalona Ramos, 1946) y en la estructura 59 de Tulum (Lothrop, 1924).

El dintel, remetido y de una sola pieza, presenta varias capas de pintura al fresco de colores azul y rojo, pero no se distingue motivo alguno. Este templo tuvo en su interior un altar adosado al muro posterior del cuarto, el cual prácticamente desapareció cuando se deslizó la parte posterior del edificio hacia atrás. El muro tenía restos de pintura roja en su interior. La exploración determinó una sucesión de pisos de grosor, espesor y acabado variables. Adosado al muro norte del cuarto había una banqueta constituida por dos hiladas de piedra, recubiertas por uno de los pisos del cuarto.

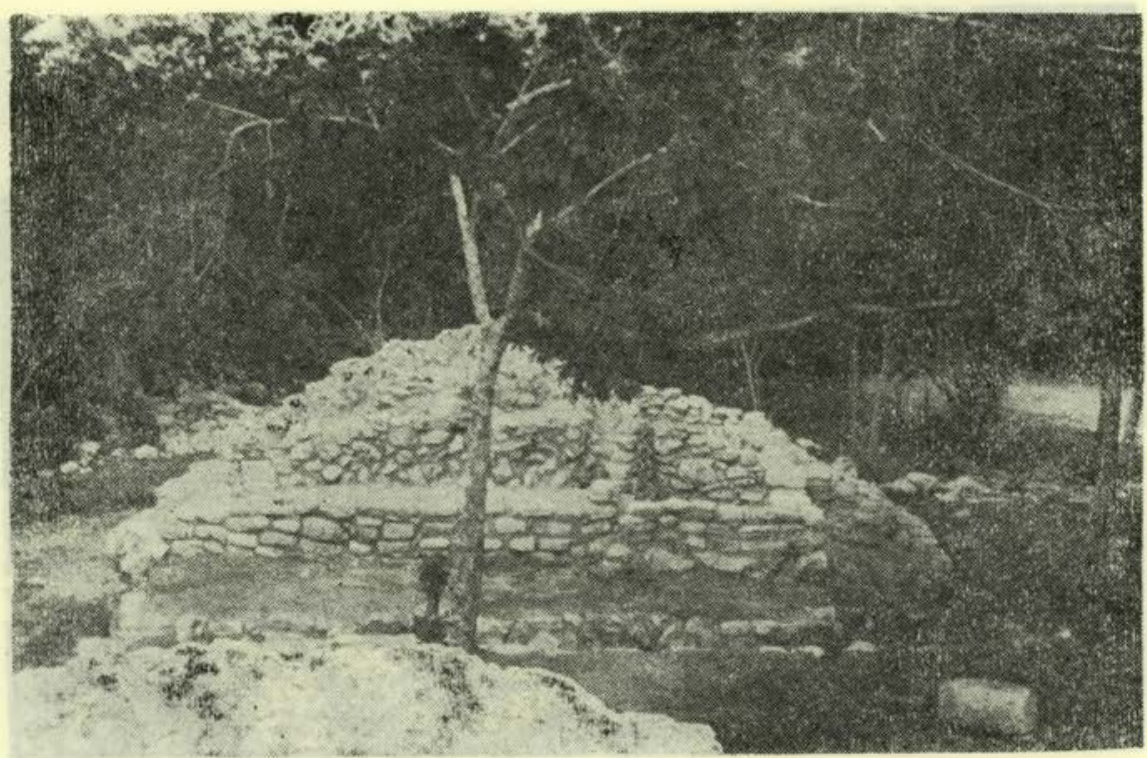

Lámina 9a. El Caracol, visto desde el templo A-VI. 


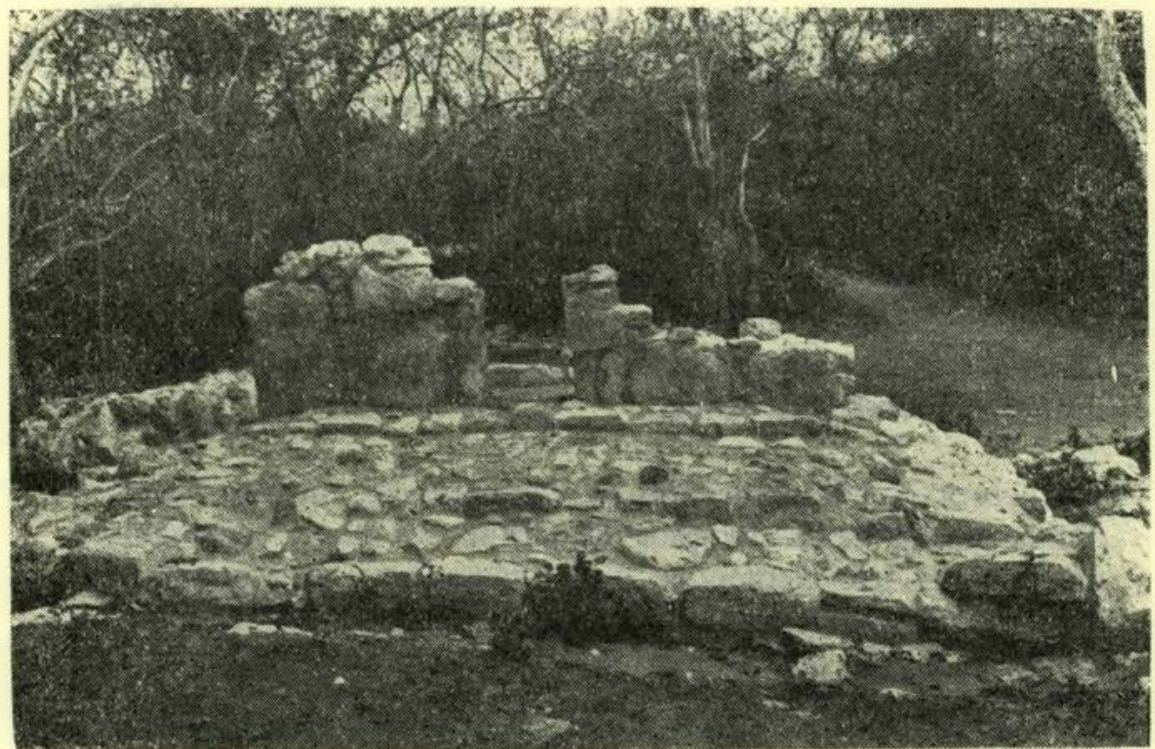

Lámina 9b. Estructura A-IX vista de frente. Esta estructura tenía una plataforma de grandes dimensiones en comparación con las de los otros edificios.

Entre el escombro que dejó el desplome del templo se halló un fragmento de pintura mural al fresco, que representa a un personaje de pie, de perfil con las piernas abiertas. Lleva un tocado de plumas, sandalias, faldín y collar. En la mano lleva una especie de flor de la cual sale un objeto largo y trenzado. Del otro brazo le cuelga lo que parece ser una bolsa de copal. Detrás de él, aparece otro personaje vegetal que posiblemente represente al maíz joven (Con, en preparación) (lám. 16).

$\mathrm{Al}$ pie de la escalinata que conduce al templo $\mathrm{A}-\mathrm{V}$ se halla un pequeño altar cuadrado recubierto con una gruesa capa de estuco. Dos altares paralelos más se encontraron al pie de la otra escalinata (fig. 4; láms. 7a, 7b). No tenían ninguna ofrenda en su interior, pero esparcidos, alrededor de ellos encontramos fragmentos de lo que Stephens bautizó como "piñas", ya que recuerdan la forma de la fruta (Stephens, 1963: 280).

Estos adornos son comunes a la arquitectura de la costa oriental y se han encontrado en Tulum (Stephens, 1963; 
Lothrop, 1924; Fernández, 1941), Akumal (Mason, 1927), Xaac y Xcaret (Andrews, 1975: 65). Este último autor los describe como adornos de plaza, consistentes en lajas clavadas en los pisos y recubiertas con una gruesa capa de estuco y las asocia a pequeñas plataformas cuadradas. Los fragmentos que nosotros hallamos no estaban asociados a ninguna laja, y aunque no estaban in situ debieron de asociarse a los altares. Los fragmentos claramente mostraban en su interior las huellas de haber tenido un armazón a base de pequeñas ramas que después recubrían de estuco.

Estructura A-VII. Este edificio comparte las mismas características de los demás templos del Grupo A: planta rectangular, moldura de tres elementos, dintel remetido y una plataforma o banqueta que le sirve de base, de manera que le deja al frente un amplio zócalo con un escalón al centro (figs. 4, 12; lám. 8a). En su interior, cuenta con un altar de planta rec-

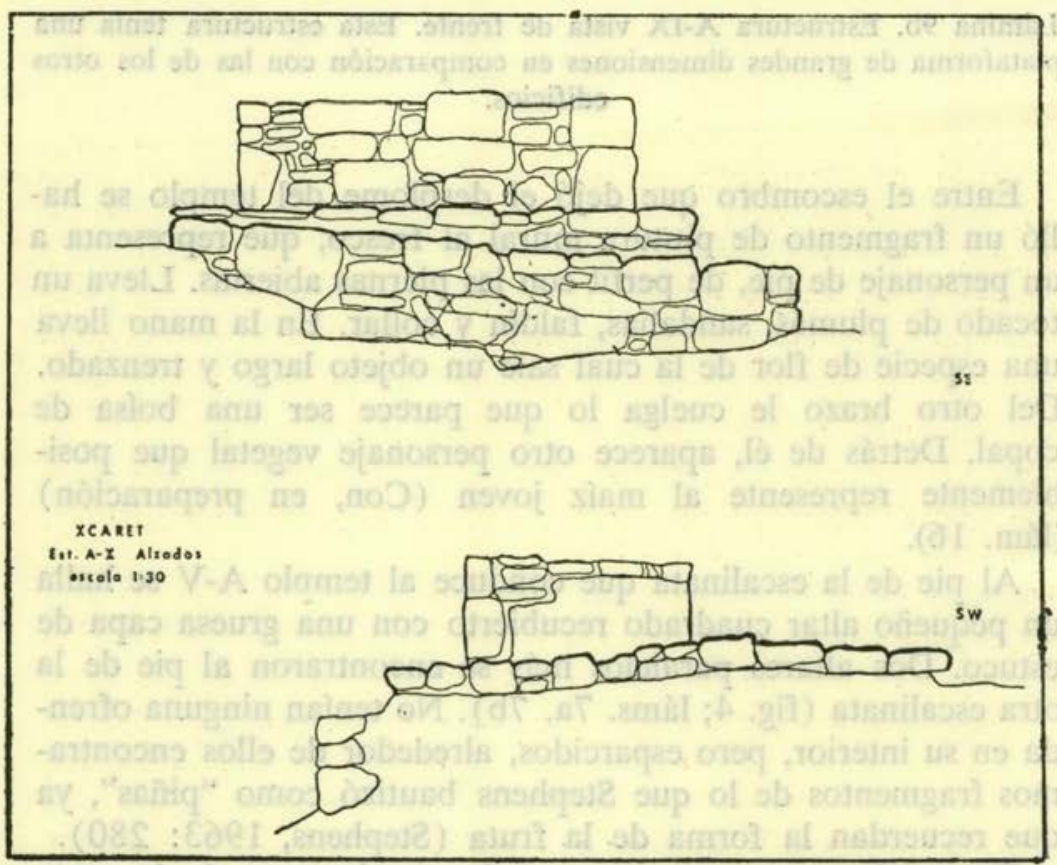

Figura 17. La estructura A-X se encontraba a orillas del acantilado, donde se forma una especie de cenote. 
tangular pegado al muro posterior, con una cavidad circular al centro, el cual se encontraba saqueado.

Entre el escombro producto de éste, encontramos un caracol Cymatium femorale que seguramente era parte de la ofrenda. Esta misma especie fue hallada como ofrenda en los altares de las estructuras A-IX y A-X.

En el dintel aún quedan restos de varias capas de estuco con pintura al fresco de color rojo. Sobre la fachada, a un lado del vano izquierdo de la puerta, se aprecia una mano izquierda en positivo, de color rojo.

Estructura A-VIII (El Caracol). De planta redonda, cuyos cuerpos están conformados semejantes a un caracol. El primer cuerpo en sus lados sur y este está constituido por grandes piedras ligeramente trabajadas, las cuales están haciendo las veces de contrafuerte y al mismo tiempo conformando la plataforma de la Plaza del Grupo A (figs. 4, 13, 14). Los muros no sólo acusan la forma circular sino que estaban finamente tallados en redondo.

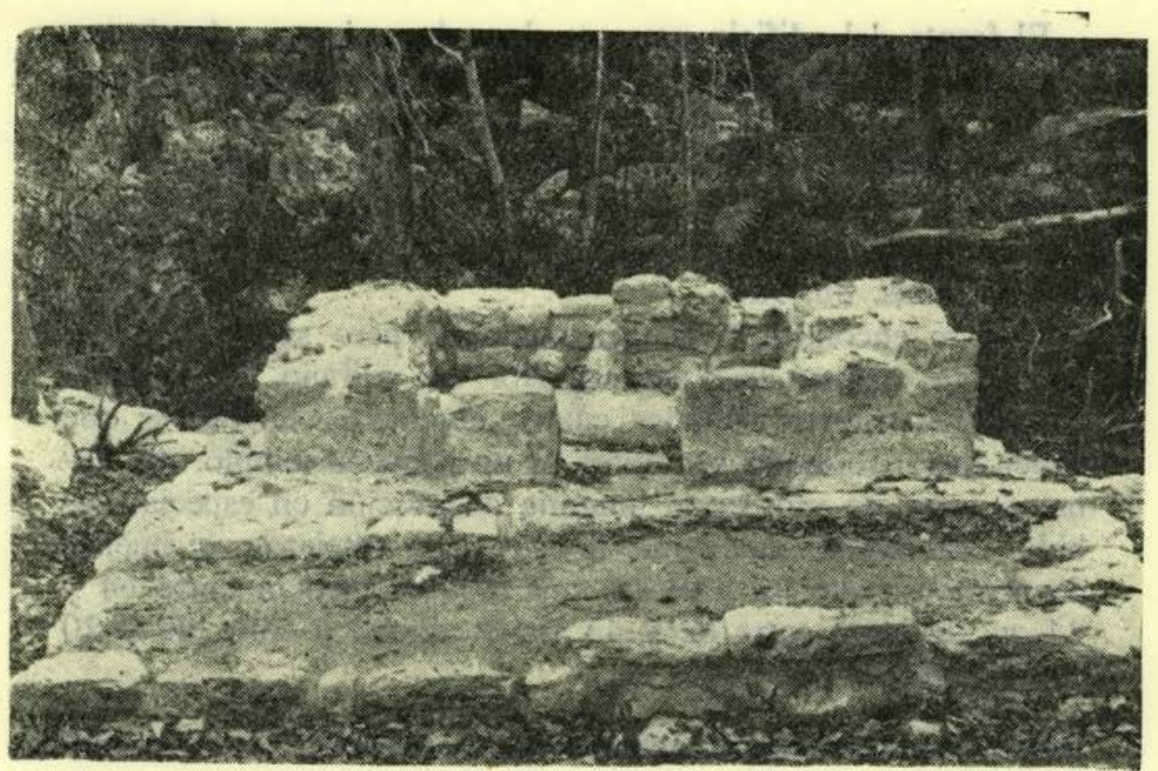

Lámina 10a. Estructura A-X, nótese el pequeño altar con la estalagmita. En la parte posterior se forma un cenote. 


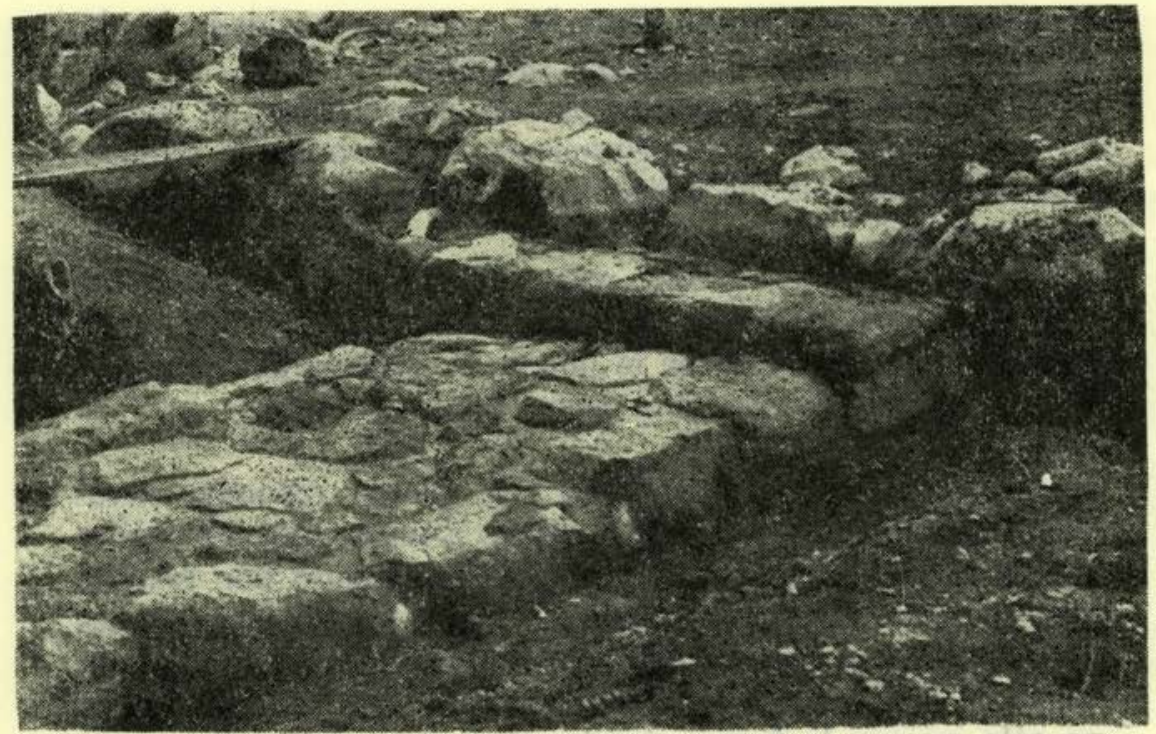

Lámina 10b. Calzada de acceso a la plataforma sobre la que descansa el Grupo A.

El frente del edificio presenta dos adosamientos, el primero compuesto por dos muros que posiblemente formaran los paramentos de la primera escalinata que tuvo el templo.

Posteriormente, se le agregó un segundo adosamiento recubriendo al primero, que le dio la forma cuadrada al frente, aumentándole finalmente la escalinata que ahora está aparente (fig. 4; láms. 8b, 9a).

Sólo se encontraron cuatro escalones, pero seguramente la escalinata alcanzó la parte superior del edificio. En la cima del edificio fueron hallados cuatro bloques rectangulares que deben haber formado los muros de un pequeño templo, sin embargó éstos no mostraron ninguna disposición en especial debido a los árboles que sobre la estructura crecieron, ni huellas de argamasa que los unieran. Los bloques medían entre 64 y $44 \mathrm{~cm}$ de largo entre 62 y $43 \mathrm{~cm}$ de ancho y entre 60 y 20 $\mathrm{cm}$ de grosor.

Estructura A-IX. Este edificio se encontró sumamente destruido, por lo que solamente después de la excavación se pudo definir con claridad. De planta rectangular, sólo conservaba 


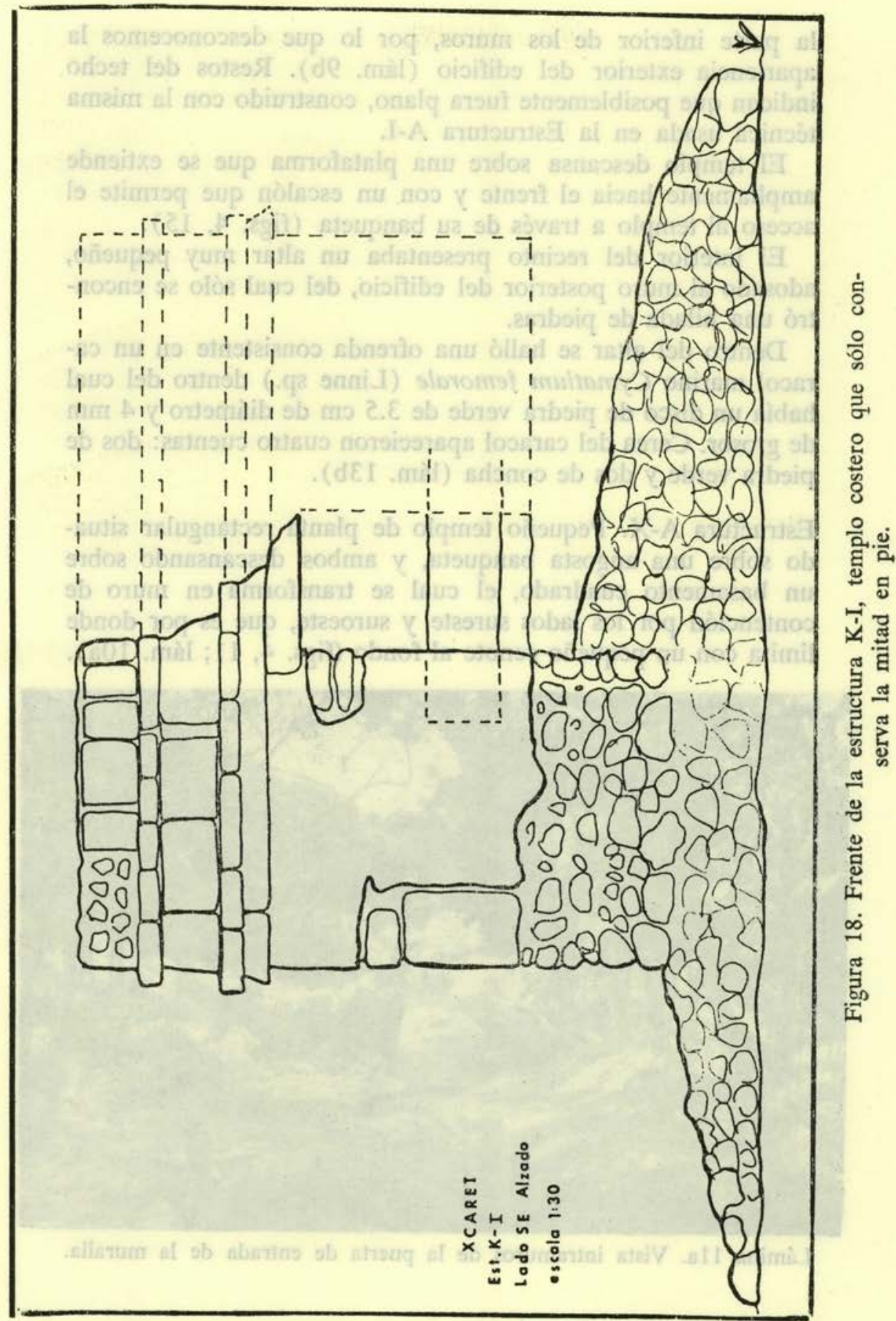


la parte inferior de los muros, por lo que desconocemos la apariencia exterior del edificio (lám. 9b). Restos del techo indican que posiblemente fuera plano, construido con la misma técnica usada en la Estructura A-I.

El templo descansa sobre una plataforma que se extiende ampliamente hacia el frente y con un escalón que permite el acceso al templo a través de su banqueta (figs. 4, 15).

$\mathrm{El}$ interior del recinto presentaba un altar muy pequeño, adosado al muro posterior del edificio, del cual sólo se encontró una hilada de piedras.

Dentro del altar se halló una ofrenda consistente en un caracol marino Cymatium femorale (Linne sp.) dentro del cual había un disco de piedra verde de $3.5 \mathrm{~cm}$ de diámetro y $4 \mathrm{~mm}$ de grosor. Cerca del caracol aparecieron cuatro cuentas: dos de piedra verde y dos de concha (lám. 13b).

Estructura A-X. Pequeño templo de planta rectangular situado sobre una angosta banqueta, y ambos descansando sobre un basamento cuadrado, el cual se transforma en muro de contención por los lados sureste y suroeste, que es por donde limita con un pequeño cenote al fondo (figs. 4, 11; lám. 10a).

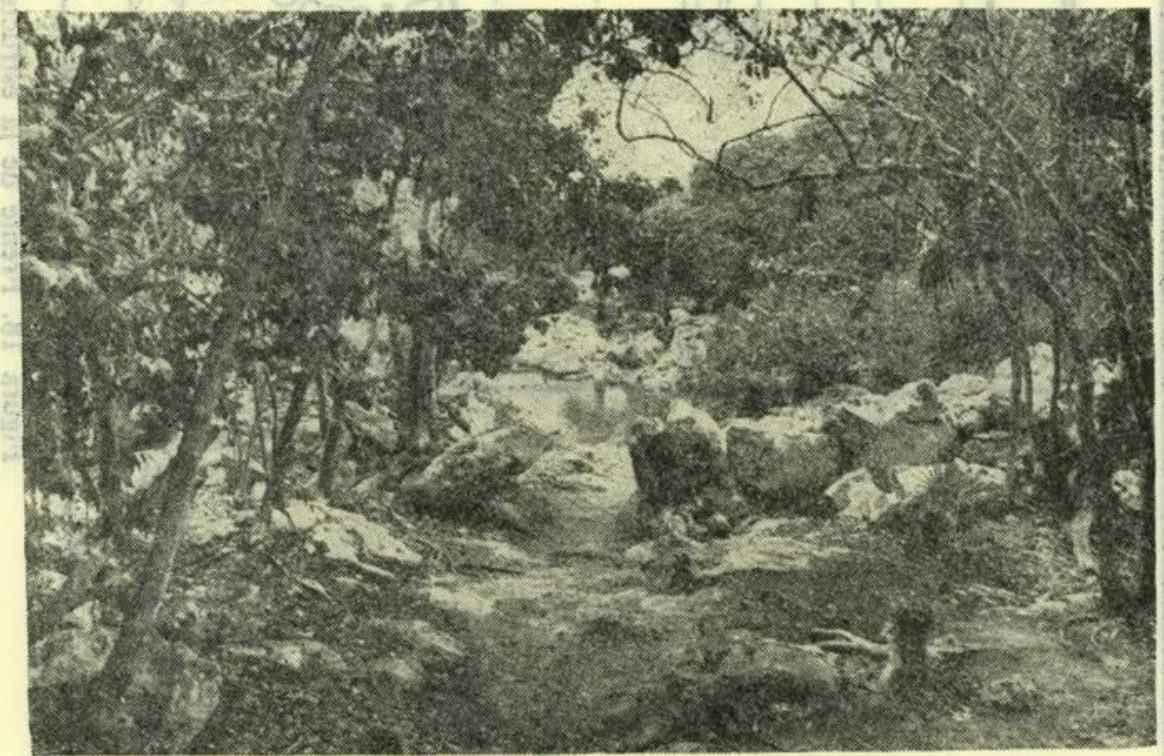

Lámina 11a. Vista intramuros de la puerta de entrada de la muralla. 


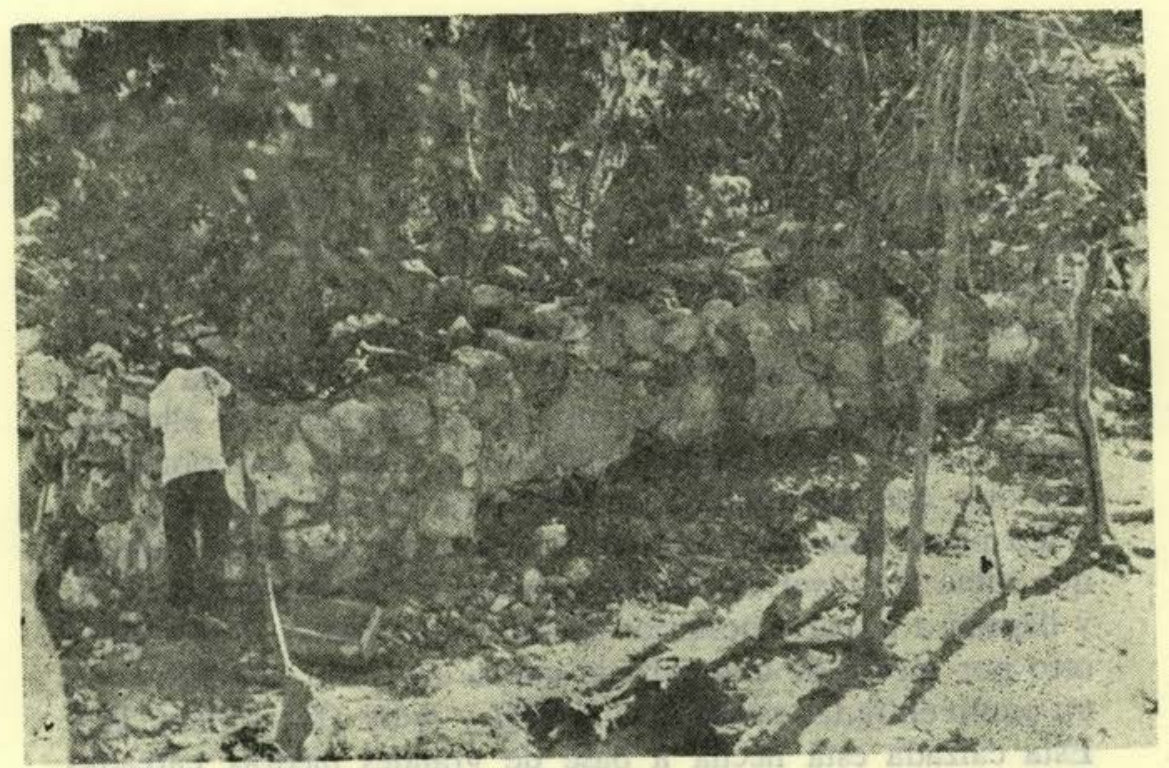

Lámina 11b. La muralla vista desde el norte en su porción correspondiente a la caleta.

Al igual que el A-IX, no se encontró completo, sin embargo se vio que el techo era abovedado.

La fachada presenta un angosto vano de entrada, y tanto el muro frontal como el posterior son de una sola hilada de piedras; los muros laterales de doble hilada (figs. 16, 17). En él interior se encontró intacto un altar construido con dos losas: una más gruesa y ancha pegada al muro trasero y otra más delgada y estrecha al frente de la otra, ambas estucadas. Sobre la losa posterior se empotró una estalagmita (lám. 10a). Bajo el altar se encontró un caracol marino Cymatium femorale y cuatro cuentas de piedra verde.

Con anterioridad mencionábamos que el Grupo A se encuentra asentado sobre una terraza artificial construida sobre el risco natural. Esta terraza conforma los límites del grupo, quedando fuera solamente la estructura A-X, que se encuentra a un nivel más bajo al de la plaza. La nivelación del terreno se hizo colocando primero una capa de grandes piedras sobre la roca natural, encima de ella otra de piedras más pequeñas, agregando tierra para sellar los intersticios, agregando luego 
una capa de sascab muy compactada, que finalmente se recubriría con estuco. Esta nivelación fue necesaria, sobre todo hacia el sur y oeste de la plaza, donde el nivel de la roca madre desciende considerablemente.

Durante las excavaciones en la plaza del Grupo A, se vio que esta plataforma artificial tuvo una fase más reducida que incluía tan sólo a la Estructura A-V-VI, y cuyo acceso estaba ligeramente más al sur del paño del centro de la Estructura A-V-VI. Esta plataforma era de esquina redondeada en su esquina suroeste. No se encontró la continuación de ella más hacia el norte. Esta primera plataforma se unió posteriormente con otra que sustentaba a la Estructura A-VIII (fig. 4).

La plaza tenía dos accesos: uno a través de una escalinata que subía del nivel en donde se encuentra la Estructura A-X, y llegaba a la parte posterior de las estructuras A-II y A-III, y otro por medio de una calzada que se une a la plataforma en un punto entre las estructuras A-VIII y A-IX (fig. 4; lám. 10). Esta calzada está hecha a base de grandes piedras careadas hacia el exterior y piedras medianas al centro. Tiene un solo escalón, ya que usa a la plataforma, a la que se adosa como un segundo. Aunque se hicieron sondeos para ver de dónde provenía dicha calzada, sólo se encontró el pequeño tramo que aparece en el plano (fig. 4).

\section{Grupo B}

Está localizado al norte del Grupo A (fig. 3), y se encuentra sumamente saqueado. Andrews (1975: 19-20) menciona que consta de siete estructuras y que tanto la disposición como las dimensiones de este grupo lo hacen diferente a los demás grupos. Las siete estructuras mencionadas por dicho autor no son observables con claridad. Pudimos apreciar sin embargo, que este grupo consta de una serie de enormes plataformas bajas no definibles muy claramente en cuanto a sus límites, que alternan con estructuras muy destruidas. No queda en ningún edificio el templo superior.

\section{Grupo C}

Lo componen cuatro estructuras y varias plataformas habitacionales, siendo el único grupo "extramuros" (en una zona 


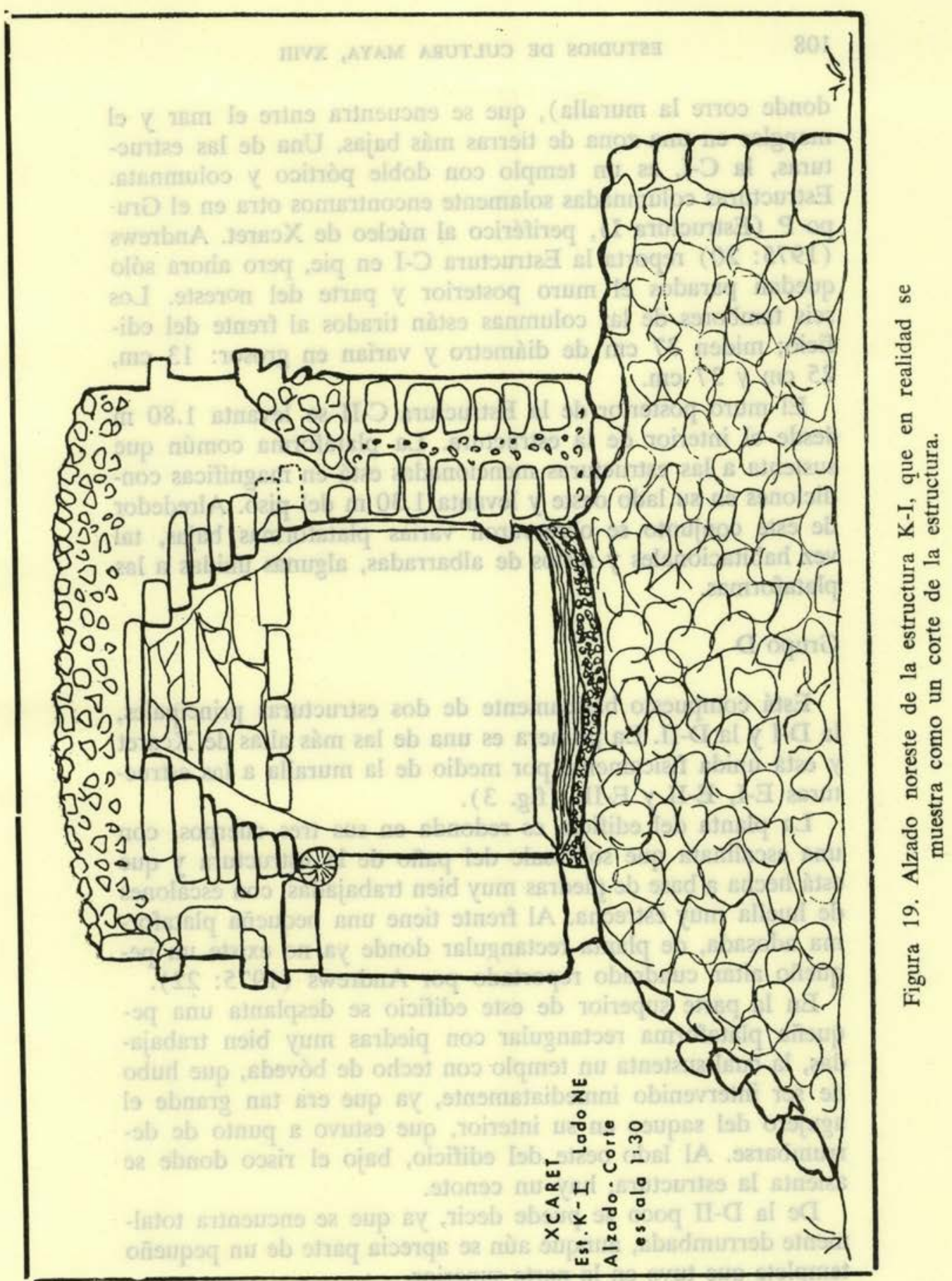


donde corre la muralla), que se encuentra entre el mar y el manglar en una zona de tierras más bajas. Una de las estructuras, la C-I, es un templo con doble pórtico y columnata. Estructuras columnadas solamente encontramos otra en el Grupo $\mathrm{P}$ (Estructura I), periférico al núcleo de Xcaret. Andrews (1975: 20) reporta la Estructura C-I en pie, pero ahora sólo quedan parados el muro posterior y parte del noreste. Los seis tambores de las columnas están tirados al frente del edificio; miden $37 \mathrm{~cm}$ de diámetro y varían en grosor: $13 \mathrm{~cm}$, $25 \mathrm{~cm}$ y $37 \mathrm{~cm}$.

El muro posterior de la Estructura C-II se levanta $1.80 \mathrm{~m}$ desde el interior de la estructura. La plataforma común que sustenta a las estructuras mencionadas está en magníficas condiciones en su lado oeste y levanta $1.30 \mathrm{~m}$ del piso. Alrededor de este conjunto se observaron varias plataformas bajas, tal vez habitacionales y restos de albarradas, algunas unidas a las plataformas.

\section{Grupo D}

Está compuesto básicamente de dos estructuras principales, la D-I y la D-II. La primera es una de las más altas de Xcaret y está unida físicamente por medio de la muralla a las estructuras E-I, E-II y E-III (fig. 3).

La planta del edificio es redonda en sus tres cuerpos, con una escalinata que sobresale del paño de la estructura y que está hecha a base de piedras muy bien trabajadas, con escalones de huella muy estrecha. Al frente tiene una pequeña plataforma adosada, de planta rectangular donde ya no existe un pequeño altar cuadrado reportado por Andrews (1975: 22).

En la parte superior de este edificio se desplanta una pequeña plataforma rectangular con piedras muy bien trabajadas, la cual sustenta un templo con techo de bóveda, que hubo de ser intervenido inmediatamente, ya que era tan grande el agujero del saqueo en su interior, que estuvo a punto de derrumbarse. Al lado oeste del edificio, bajo el risco donde se asienta la estructura, hay un cenote.

De la D-II poco se puede decir, ya que se encuentra totalmente derrumbada, aunque aún se aprecia parte de un pequeño templete que tuvo en la parte superior. 


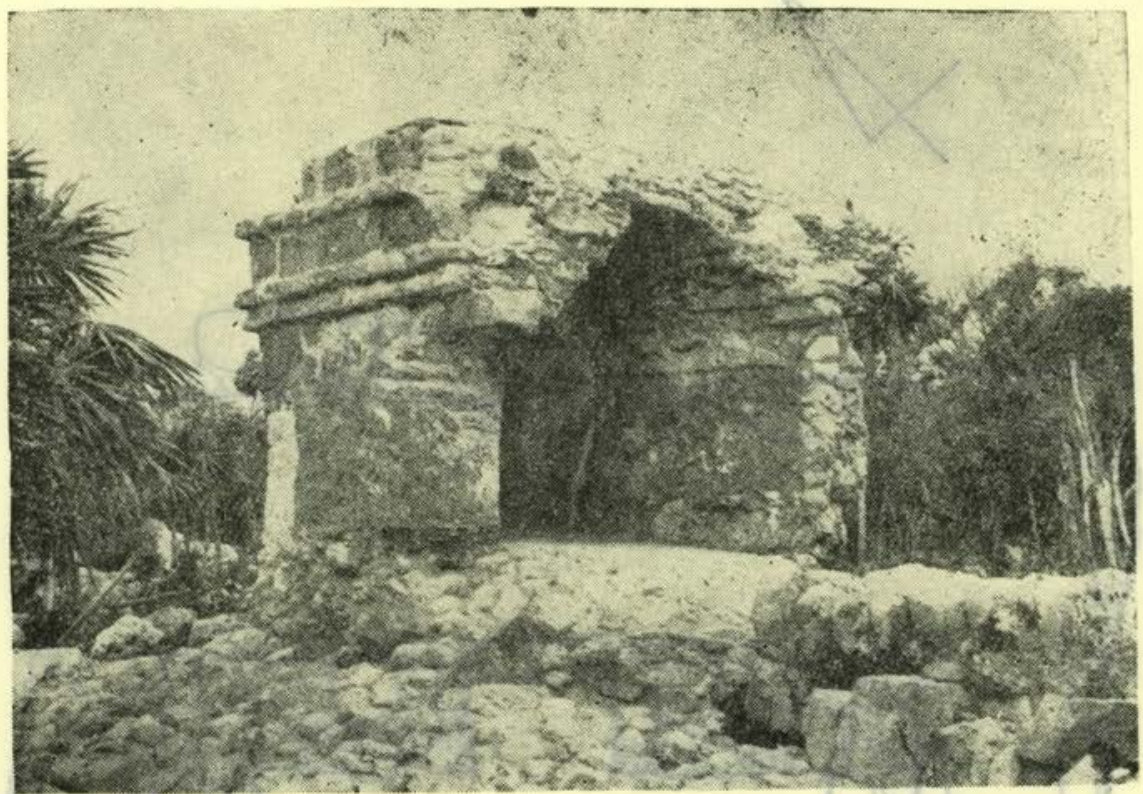

Lámina 12a. Estructura K-I, de la cual queda solamente la mitad, pero que ofrece una clara visión de la técnica constructiva usada.

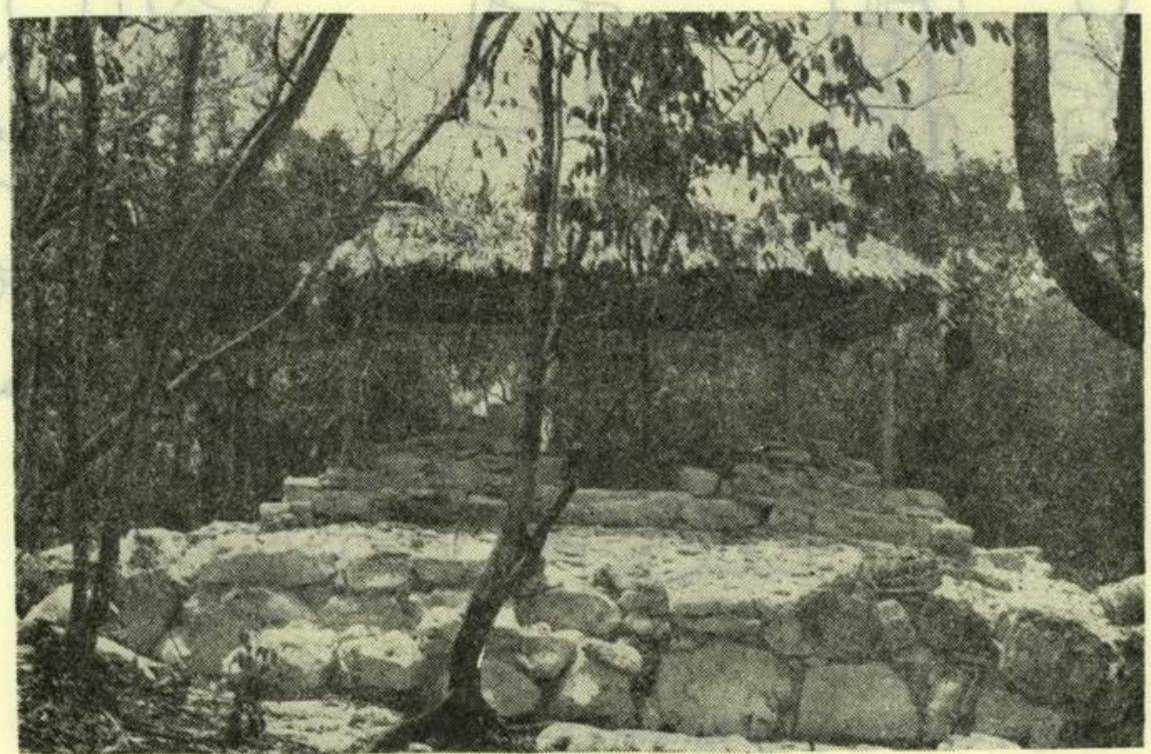

Lámina 12b. Vista de la estructura K-II. 

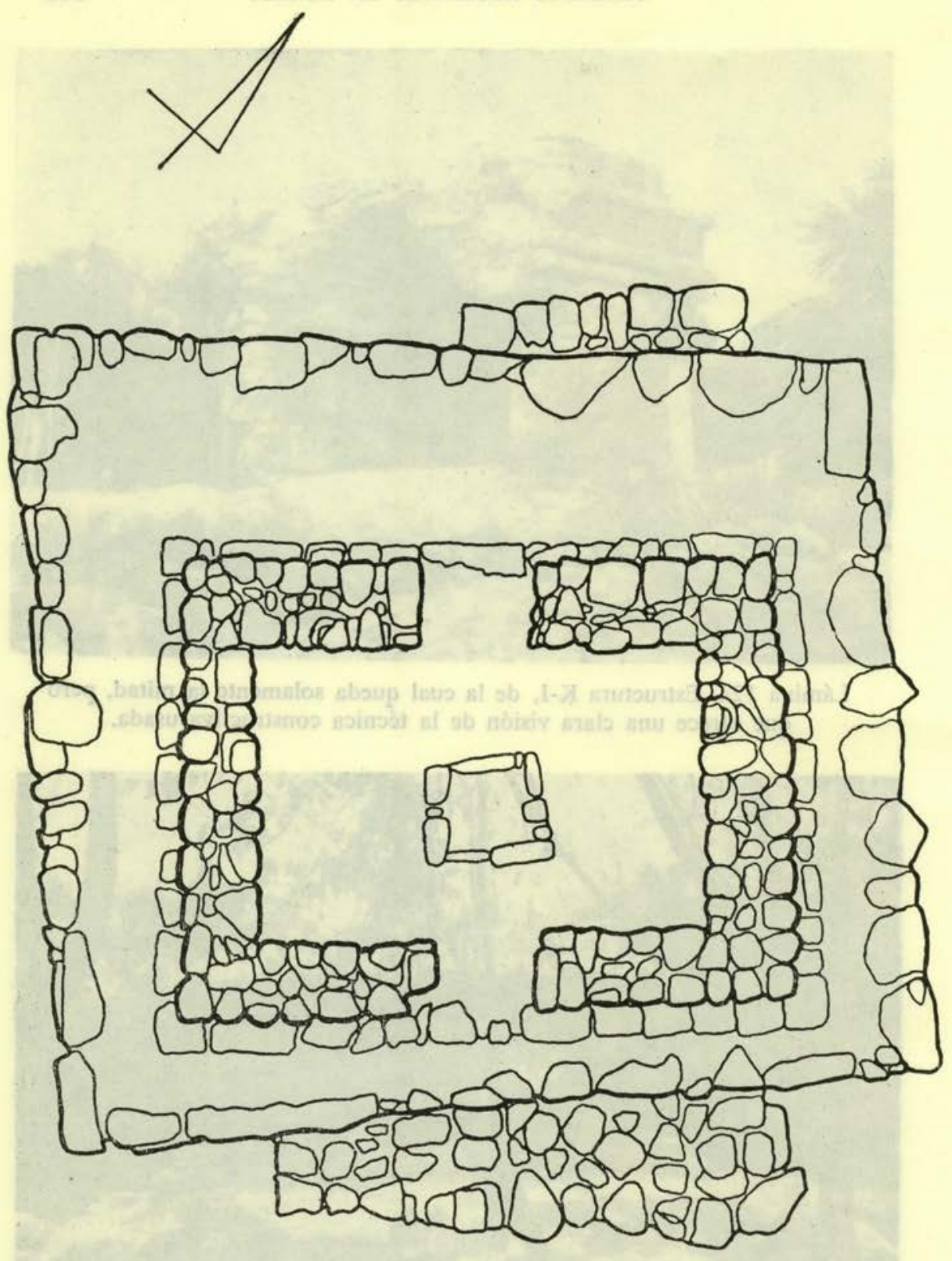

Figura 20. Planta de la estructura K-II. 
Frente al edificio D-I hay una disrupción de la muralla, la cual no sabemos si se trata de una antigua entrada [como lo supone Andrews (1975: 22)], que comunicaba con el Grupo C o se trate de una entrada moderna hecha por los propietarios del rancho para el paso del ganado. Lo que sí es claro es que no existen rastros de un acceso formal como lo tiene en la caleta.

\section{Grupo E}

Este conjunto consta de seis estructuras que se encuentran sobre la parte alta del risco (fig. 3) (Andrews, 1975: fig. 28).

La Estructura E-I que se adosa a la E-II, consta de un templo de un solo cuarto que descansa sobre una plataforma alargada que se une a la muralla por el sur. El techo era plano y se encuentra colapsado hacia el este, quedando en pie sólo el muro sur y la fachada.

La Estructura E-II descansa sobre una plataforma de planta cuadrada, con su lado este muy bien conservado, mismo por

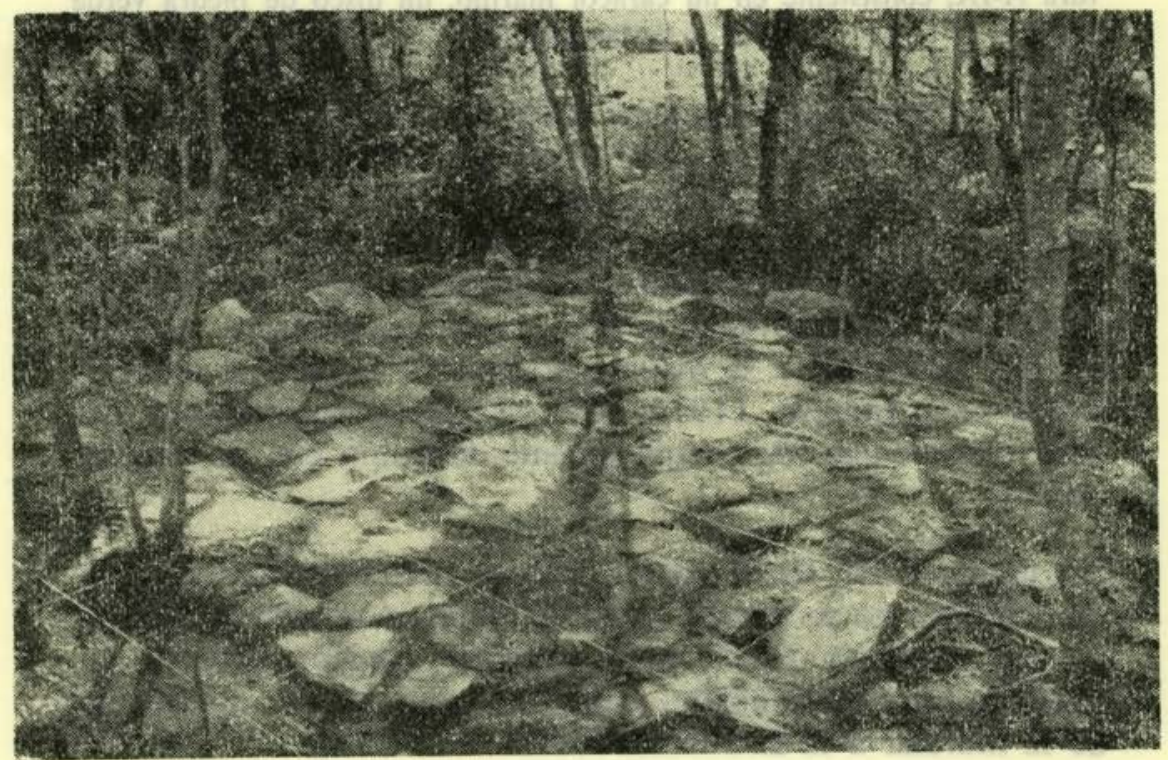

Lámina 13a. Empedrado de una de las estructuras habitacionales encontradas cerca del Grupo A. Algunas de las piedras utilizadas eran de reúso de las estructuras mayores. 


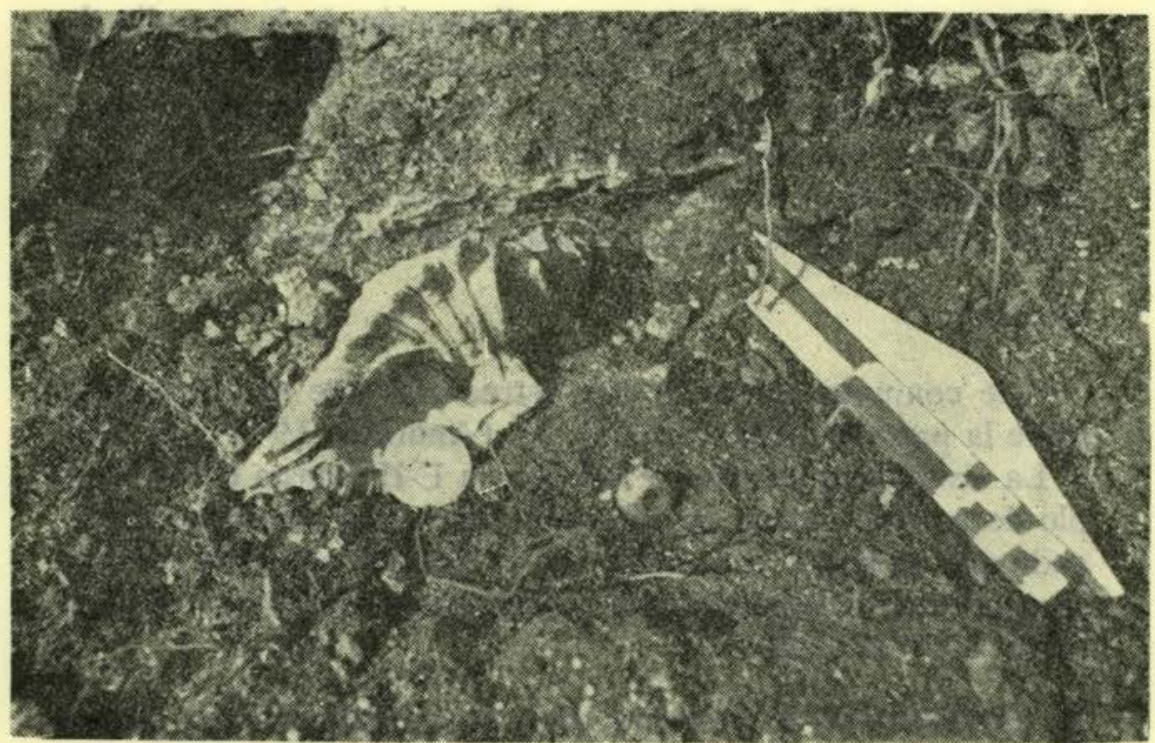

Lámina 13b. Ofrenda encontrada en el interior del altar de la estructura A-IX, consistente en un caracol marino, un disco de piedra verde y varias cuentas.

el que se une a la Estructura E-III por medio de la muralla. En su lado norte tiene una escalinata remetida, de la cual solamente quedan bien conservados los últimos escalones. El templo superior es de un solo cuarto con techo abovedado, y dintel remetido que conserva varias capas de estuco con pintura. Las molduras sólo pueden verse en la parte este del templo, pero ya no se distinguen los tres elementos mencionados por Andrews (1975: 26). Tampoco queda nada del altar interior que fue completamente destruido por los saqueadores.

Estructura E-III. Es de planta circular, pero debido a su grado de deterioro no se aprecia ya la escalinata con alfardas descritas por Andrews. En la parte superior quedan restos de un templete muy derrumbado. Esta estructura se une por medio de la muralla a la Estructura E-II.

Estructura E-IV. Aunque reportada por Andrews como cuadrada (Andrews, 1975: 31; fig. 28), posiblemente sea también 
de planta circular como parece observarse en su lado este. Es difícil determinar el número de cuerpos que la forman. Tiene una escalinata remetida, con alfarda, fácilmente observable en el último cuerpo. La corona un templete circular que descansa sobre una banqueta redonda. Quedan en pie las jambas de la puerta y el techo está colapsado hacia la parte posterior del edificio. Andrews (1975: 26) pudo observar que la techumbre era plana. De la esquina norte de este edificio sale la muralla en esa misma dirección.

Estructura E-V. Es un pequeño templo que descansa sobre una banqueta que se encuentra a un lado y al pie de la escalinata de la estructura anterior. Sólo la parte frontal del edificio queda en pie, el techo se encuentra derrumbado hacia el interior del templo.

Estructura E-VI. Sobre una plataforma con escalinata remetida al centro, se levanta un templo que tiene otro menor en su interior, ambos en bastante buen estado de conservación, aunque saqueados. Básicamente se encuentra como Andrews la describe (1975: 26; fig. 28).

\section{Grupo F}

Está conformado por tres estructuras asentadas sobre una gran plataforma escalinada. La Estructura F-I es la de mayor tamaño y una de las más grandes de Xcaret. Un gran árbol que creció en el interior y al centro de ella destruyó gran parte del edificio quedando en pie la fachada y parte de los muros laterales. Las estructuras F-II y F-III que son dos pequeños templos están totalmente colapsados (fig. 3) (Andrews, 1975: 27-30; figs. 34-37).

\section{Grupo G}

Se encuentra a unos cuantos metros del grupo anterior (fig. 4). Lo constituye la capilla española que está cerca de una rejollada que en su extremo noreste tiene una especie de muro o rampa que sube hasta el nivel de la construcción. 


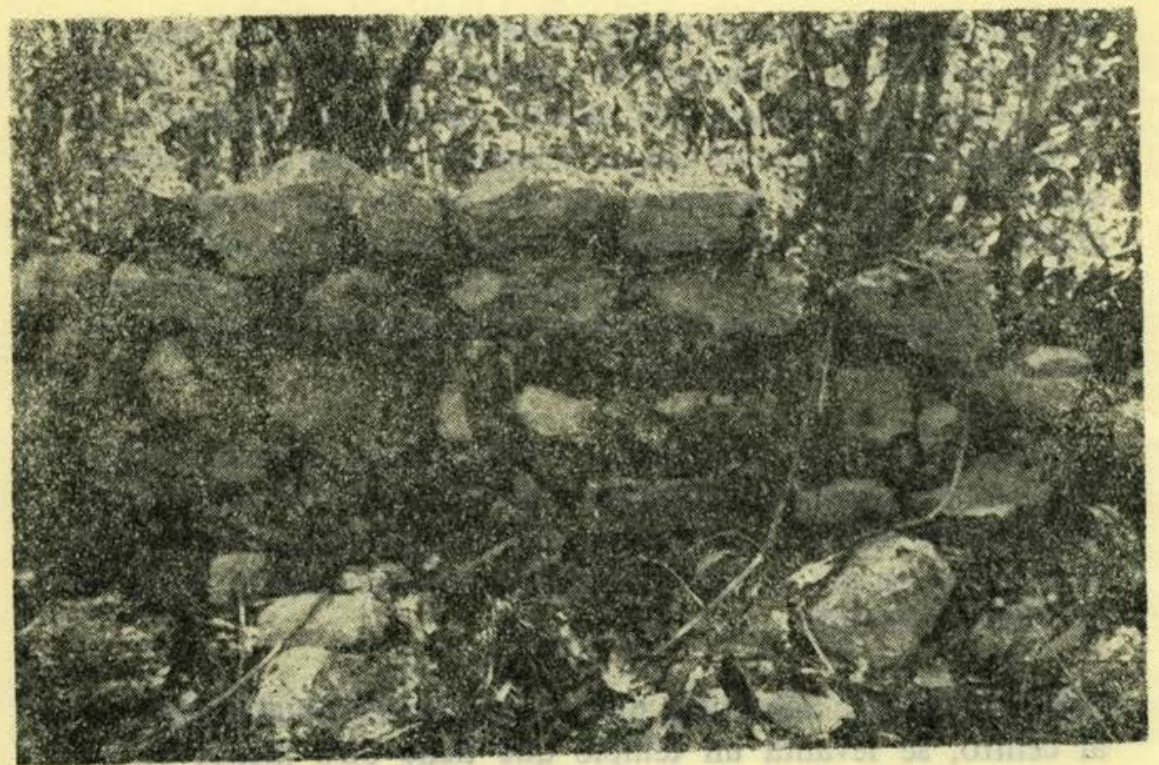

Lámina 14a. Restos de la barda atrial de la capilla española.

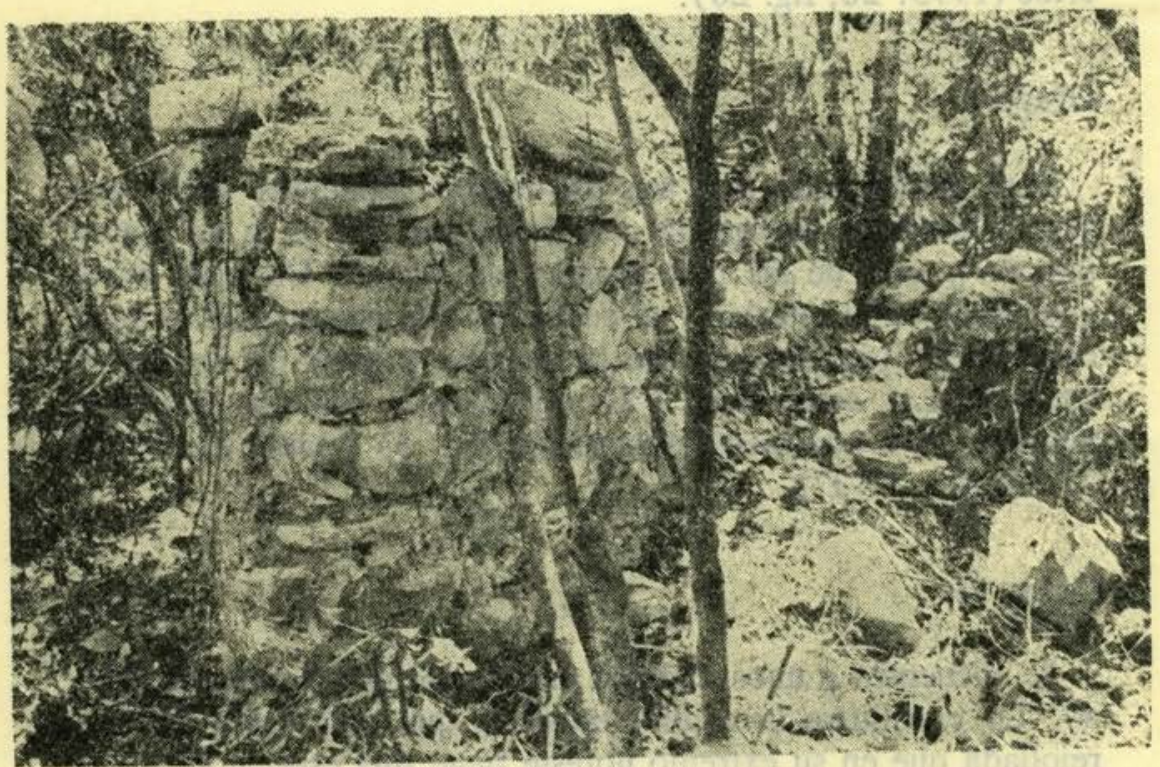

Lámina 14b. Muro que conformaba la capilla. 
Esta capilla es del tipo abierto (Andrews, 1975: 30-32), y tiene una barda atrial que aún se levanta hasta $70 \mathrm{~cm}$ en su lado oeste (fig. 39). Está hecha a base de piedras unidas con un mortero mezclado con piedras más pequeñas. Llevaba un grueso recubrimiento de estuco de más de $3 \mathrm{~cm}$ y los bordes superiores de la barda estaban redondeados (lám. 14a).

La barda tiene tres entradas: dos laterales casi al centro del muro hacia el norte y sur y la principal hacia el oeste. El lado este de la barda es $5 \mathrm{~m}$ más ancha, y no como lo ilustra Andrews (1975: fig. 39). Tampoco la capilla presenta una alineación equidistante con la barda, sino que se encuentra ligeramente girada hacia el noroeste en relación a ésta (fig. 3).

Se conserva en pie la esquina noreste de la capilla con aproximadamente $1.28 \mathrm{~m}$ de altura al interior y $1.50 \mathrm{~m}$ al exterior. Esta esquina es redondeada y presenta la misma técnica constructiva que la barda (lám. 14b).

En su muro norte tenía una ventana de $1.20 \mathrm{~m}$ de ancho, que conservaba la huella de la base del poste, de $16 \mathrm{~cm}$ de diámetro. Sobre este mismo lado norte, pero más hacia el este se encuentra otro acceso a la capilla. Aquí el muro tiene $1.50 \mathrm{~m}$ de altura y $55 \mathrm{~cm}$ de grosor.

En su lado este, ahora prácticamente derrumbados, se encuentran el altar central que está separado del muro posterior como $2 \mathrm{~m}$, y otra especie de pequeño altar o banqueta de $1.50 \mathrm{~m}$ de ancho, y $38 \mathrm{~cm}$ de altura, adosado a la esquina noreste (redondeada).

La puerta sur de la capilla muestra un vano redondeado y se levanta $70 \mathrm{~cm}$ sobre el piso interior, aquí el muro tiene $70 \mathrm{~cm}$ de grosor. La techumbre aparentemente era de material perecedero, ya que no hay otro tipo de cubierta en el escombro. Frente a la entrada principal encontramos los cimientos de lo que posiblemente fue la residencia del cura. La plataforma no sobrepasa los $20 \mathrm{~cm}$ de altura y tiene una escalinata de $80 \mathrm{~cm}$ de ancho, con dos hiladas de escalones, que estuvieron recubiertos con una capa de estuco de $6 \mathrm{~cm}$.

La escalinata está delimitada por piedras paradas bien careadas. Esta plataforma en su lado sur limita con una rejollada de gran tamaño, en el interior de la cual se encuentra una sascabera (fig. 3). Como a $45 \mathrm{~m}$ al oeste de la capilla, se en- 
contró un pozo con las paredes recubiertas por piedras bien careadas y con una profundidad de aproximadamente $7 \mathrm{~m}$.

\section{Grupo $\mathrm{H}$}

Este grupo fue reportado por Andrews (1975: 32) como un templo aislado a orillas del mar. Desde entonces el edificio ha sufrido un mayor deterioro, como grandes grietas que van de piso a techo y que ponen en peligro su estabilidad. El techo muestra varios desplomes de las piedras que cierran la bóveda. Del altar interior, sólo se conserva la huella en el muro posterior que ha sido totalmente destruido por el saqueo, y sobre el mismo muro, quedan huellas de estuco con pintura roja. El dintel en su lado sur está prácticamente desprendido por una fractura que llega hasta el techo.

En el curso de nuestro recorrido encontramos otra estructura a $140 \mathrm{~m}$ al norte, la cual denominamos H-II, por ser éste el grupo más cercano a ella (fig. 3 ). Se encuentra a orillas de una rejollada de aproximadamente $27 \mathrm{~m}$ de diámetro, cuya

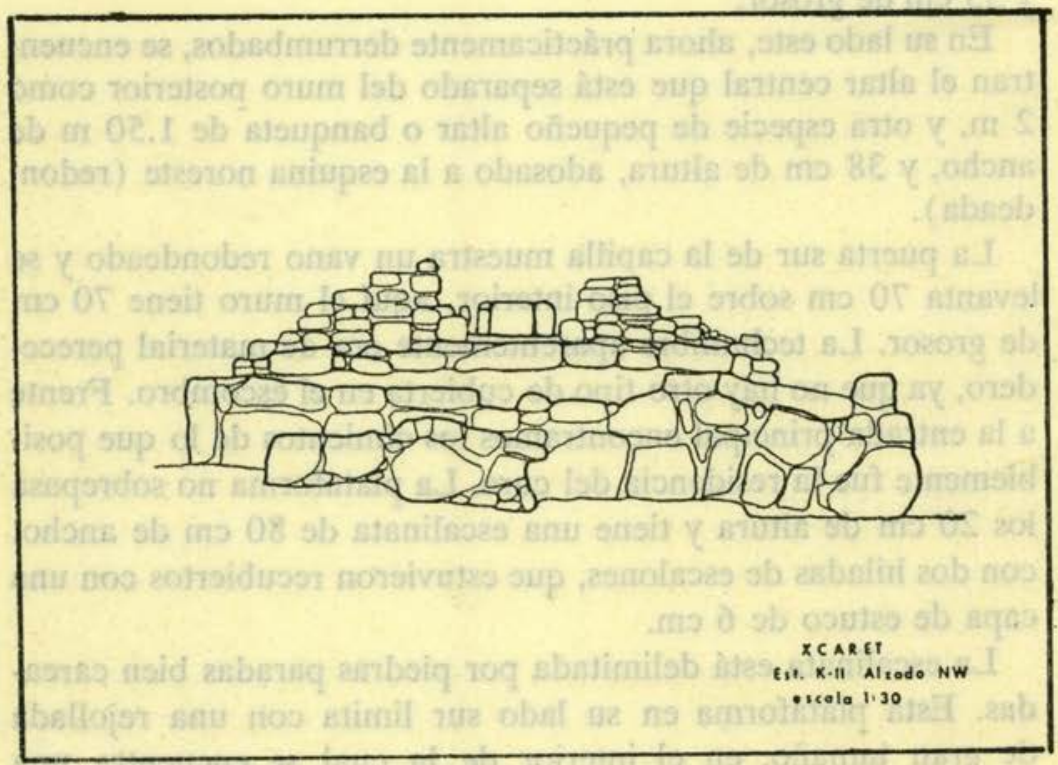

Figura 21. Lado noroeste de la estructura K-II. 
parte más profunda se encuentra al norte. El edificio está sumamente derrumbado, pero se alcanzan a distinguir algunas esquinas tanto de la plataforma como del templete superior.

\section{Grupo K}

Estructura K-I. Esta estructura situada prácticamente a orillas del mar y mirando hacia él (fig. 3), está considerada como un templo costero aislado (Andrews, 1975: 34). Descansa sobre una plataforma de grandes piedras en su base que van disminuyendo de tamaño hacia la parte superior, no parecen haber tenido argamasa. Del templo sólo queda la mitad sur, ya que la otra mitad se derrumbó completamente (figs. 18, 19; lám. 12a), en parte por el deterioro de la plataforma. El altar reportado (1975: 34) había desaparecido por completo, producto del saqueo. Innumerables pisos de estuco que recubrieron el piso del templo quedaron a la vista.

Estructura K-II. Corresponde a una nueva estructura no reportada por Andrews, a la cual le dimos la nomenclatura del gru-

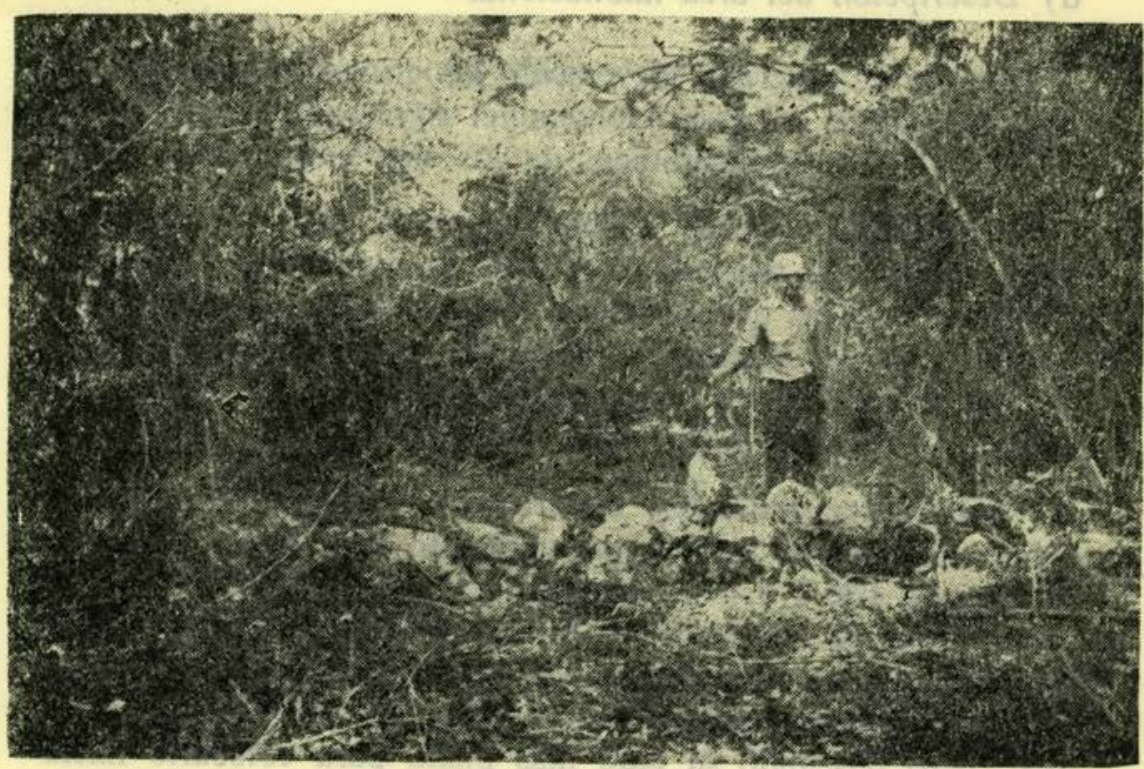

Lámina 15. Ejemplo de albarrada. 
po $\mathrm{K}$, por encontrarse cercano a él (fig. 3). Consta de una plataforma de dos cuerpos principales, el primero de los cuales está construido con enormes piedras ligeramente careadas. En la parte superior tiene una banqueta sobre la cual descansa un templo de planta rectangular, cuyos muros estaban conformados por dos hiladas de piedras careadas con un espacio al centro, dando así doble vista, tanto al exterior como al interior del muro. La altura probable de estos muros no rebasaba de $1 \mathrm{~m}$, ya que algunas partes de él se encontraban colapsados hacia el interior del recinto. El techo debió de ser perecedero (figs. 20, 21; lám. 12b).

Tiene dos entradas opuestas sobre un eje noreste-sureste (una mira hacia el mar y otra hacia tierra). En el interior encontramos un altar de planta casi cuadrada y uno de los pocos que no están saqueados del sitio. Queda la duda en cuanto a las escalinatas que llevarían hacia la parte superior, mismas que posiblemente se encontraron en uno o dos de los lados que serían hacia donde están los accesos al recinto superior (figs. $20,21)$.

\section{d) Descripción del área habitacional}

Después de describir brevemente los grupos principales, hablaremos ahora del área habitacional adyacente y conformada por elementos arquitectónicos de los siguientes tipos:

1) Plataformas: hechas a base de piedra burdamente trabajada, unidas con mortero o en seco; de dimensiones y formas variadas. Hay las que sustentan templos en su parte superior, siendo este tipo de plataformas común como estructuras aisladas en el interior o a orillas del mar como es el caso de las estructuras H-I y K-I (fig. 3).

2) Plataformas redondas, cuadradas o elípticas: son en realidad cimientos de piedra, que varían en disposición, así como en tamaño (de 1 a $4 \mathrm{~m}$ de diámetro), altura (entre 20 y 50 $\mathrm{cm}$ ) y tipo de construcción; es común que sean huecas. Las piedras que las conforman pueden ser de tamaño grande o mediano, casi siempre unidas en seco, por lo general sin carear, pero buscando su lado más plano para colocarlo hacia el exterior. 


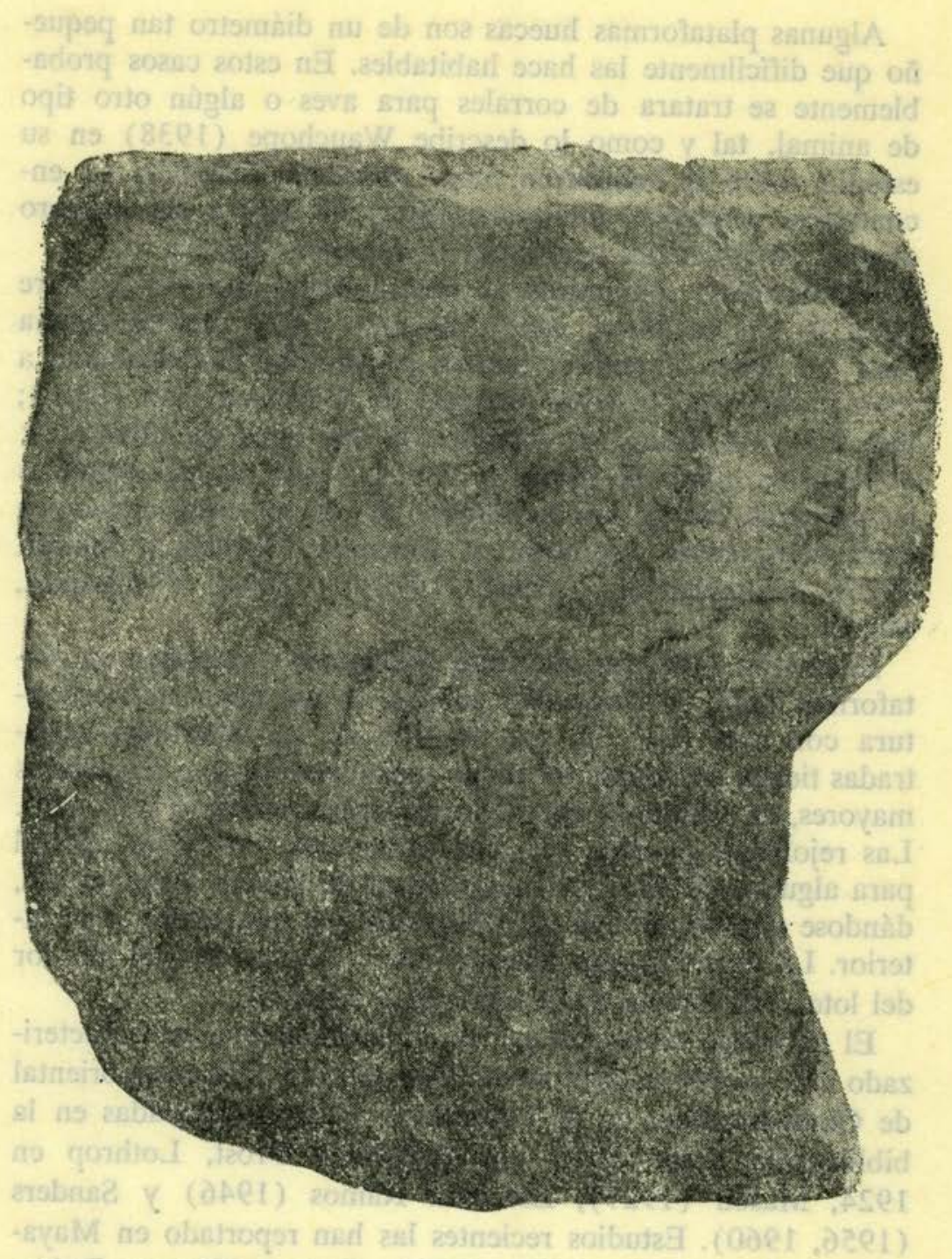

Lámina 16. Fragmento de pintura mural encontrado al interior del arlisX. (S80 I volliah) templo A-VI.

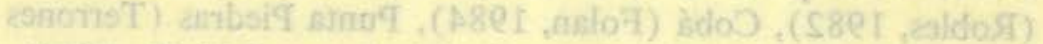

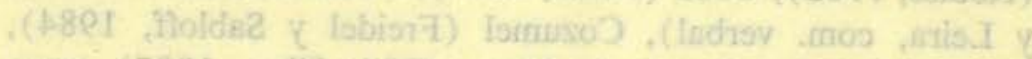

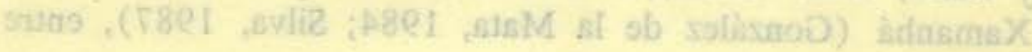


Algunas plataformas huecas son de un diámetro tan pequeño que difícilmente las hace habitables. En estos casos probablemente se tratara de corrales para aves o algún otro tipo de animal, tal y como lo describe Wauchope (1938) en su estudio sobre la habitación maya moderna. También se encontraron pequeños amontonamientos de piedra sin mortero alguno, de los cuales ignoramos su función (fig. 3).

3) Albarradas: son muros de piedra bajos que varían entre 20 y $50 \mathrm{~cm}$ de altura, unidos en seco y que conforman una "red" de lotes o predios, que se encuentran prácticamente a todo lo largo de la costa oriental de Quintana Roo (fig. 3; lám. 15). En Xcaret se encontraron dos tipos de albarradas: de una sola hilada de piedra y de dos, siendo las más comunes las primeras. No existen en ninguno de los dos casos andadores entre ellas, como aparecen en Cozumel (Freidel y Sabloff, 1984), Chunchucmil (Vlceck, 1978) y Tulum (Velázquez, 1985).

Es común encontrar que éstas comiencen o terminen en plataformas tanto huecas como sólidas, o que unan una estructura con otra (fig. 3). La mayoría de las albarradas registradas tienen en su interior una o más plataformas o estructuras mayores, en ocasiones cuevas, sascaberas, cenotes o rejolladas. Las rejolladas parecen ser, por otra parte, un límite natural para algunas de ellas, ya que parecen dirigirse o terminar allí, dándose el caso de algunas albarradas que descienden a su interior. La gran mayoría muestra uno o dos accesos al interior del lote y raramente están totalmente cerradas.

El complejo albarrada es una modalidad que ha caracterizado a la península de Yucatán y en especial a la costa oriental de Quintana Roo, en el Postclásico. Han sido tratadas en la bibliografía desde 1909 por Arnold y Frost, Lothrop en 1924, Mason (1927), Escalona Ramos (1946) y Sanders $(1956,1960)$. Estudios recientes las han reportado en Mayapán (Bullard, 1952, 1953, 1954), Tulum (Barrera Rubio, 1977; Velázquez, 1985), Tancah (Miller, 1982), Xelhá (Robles, 1982), Cobá (Folan, 1984), Punta Piedras (Terrones y Leira, com. verbal), Cozumel (Freidel y Sabloff, 1984), Xamanhá (González de la Mata, 1984; Silva, 1987), entre otros. 
4) Rejolladas: son grandes depresiones o hundimientos del terreno que a veces contienen cenotes o cuevas secas, algunas de ellas utilizadas como sascaberas, de donde obtenían material para la construcción. Algunas de las rejolladas de Xcaret son muy extensas y presentan un lugar ideal para el cultivo intensivo, dada la acumulación de suelo y el alto índice de humedad.

5) Cuevas: dadas las características kársticas de la región, las formaciones de oquedades son muy comunes. Estos espacios fueron utilizados con fines de culto, encontrándose incluso en algunos de ellos pequeños templos y ofrendas.

6) Cenotes: al igual que las cuevas los cenotes son comunes en la región y seguramente proporcionaron una fuente importante de agua fresca para la subsistencia de los habitantes del lugar. Algunos de ellos tienen asociadas estructuras de mampostería, siendo las más importantes la H-II y la A-X.

\section{COMENTARIOS FINALES}

Los sitios arqueológicos de la costa oriental de Quintana Roo se encuentran en su mayoría localizados en las proximidades del mar, algunos prácticamente en la orilla, es por ello que se supone que de alguna forma estaban orientados hacia actividades relacionadas con él, como la pesca y el comercio marítimo, actividad que se fortalece en este periodo y que unía a la costa del Golfo de México con Honduras.

Estos asentamientos van desde sitios de quinientas o más estructuras, a simples estructuras aisladas generalmente a orillas del mar que se piensa que pudieron haber sido utilizadas como puntos de referencia para la navegación, sobre todo en este tipo de costa donde no hay referencias claras para los navegantes dado lo plano del paisaje.

Con relación a la temporalidad de la costa es conveniente recordar que la mayoría de los asentamientos, con algunas excepciones, se ubican en lo que Sanders (1960) llamó Periodo Tulum, entre 1250 y 1520 d.C., por lo que el periodo de ocupación intensa de la costa entra dentro del Periodo Decadente para el norte de Yucatán o Postclásico Tardío. 
Todos estos sitios de la costa comparten los mismos rasgos arquitectónicos denominados por Lothrop (1924) como estilo Costa Oriental, es un estilo ampliamente extendido y de escasas variantes, ampliamente descritas por el mismo autor.

Para el horizonte Clásico, la ocupación en la costa no era $\tan$ intensa hasta donde hoy sabemos. Sin embargo, algunos trabajos en sitios como El Meco, Playa de Carmen, Punta Piedra, Xcaret, Tancah y otros, han producido restos cerámicos de épocas anteriores, algunas hasta del Periodo Preclásico. Sin embargo, parece que en esta época la costa estuvo prácticamente deshabitada, siendo claro que su periodo floreciente se dio a finales del Postclásico. En cambio, al interior, existieron sitios muy importantes como Cobá, Tzibanché, El Resbalón, Ichmul, etcétera.

A la llegada de los españoles, Yucatán estaba dividida en 16 provincias independientes, de ellas, sólo cuatro ocupaban la costa de Quintana Roo: Ecab, Uaymil, Cozumel y Chectemal (Roys, 1957: 3). Xcaret se encontraba dentro de la primera.

En general podemos apuntar que Xcaret presenta el mismo tipo de distribución de elementos arquitectónicos que la mayoría de los sitios de la costa oriental, es decir, los grupos de estructuras mayores cerca del mar, templos aislados en la orilla y hacia el interior una vasta red de muros o albarradas que delimitan espacios cerrados dentro de los cuales se encuentran varias estructuras de tipo habitacional.

Aunque aún no se ha definido con claridad el uso real de estos lotes, consideramos que el más viable es el habitacional, incluyendo otros tipos de estructuras domésticas como corrales, almacenes y otras áreas de actividad, tal y como se usa en la actualidad. Seguramente también fueron utilizados como huertos para obtener productos complementarios a su dieta. Dada la pobreza del suelo, y la necesidad de rotación del terreno, es poco probable que estos lotes hayan sido utilizados sólo para el cultivo, ya su construcción implica mucho trabajo. Sin embargo, no descartamos la posibilidad de que algunos de ellos sirvieran exclusivamente para este fin.

Respecto a los sacbeoob que menciona Hewen existieron, no encontramos en toda el área recorrida indicio de ningún camino. Tampoco en los recorridos realizados hacia el norte por 
Silva o hacia el sur por Terrones, a los cuales hacíamos referencia con anterioridad, se encontró indicio de ellos. Cabe la posibilidad de que estos caminos no fueran de mampostería como los de Cobá o Cozumel, sino que se tratara de antiguos caminos blancos abiertos entre la selva, y de los cuales no queda huella aparente.

Por último, queremos mencionar que aunque muchos datos existentes apuntan hacia la identificación de Polé con Xcaret, creemos prudente esperar hasta que nuevos datos tanto arqueológicos como históricos nos permitan confirmar el hecho.
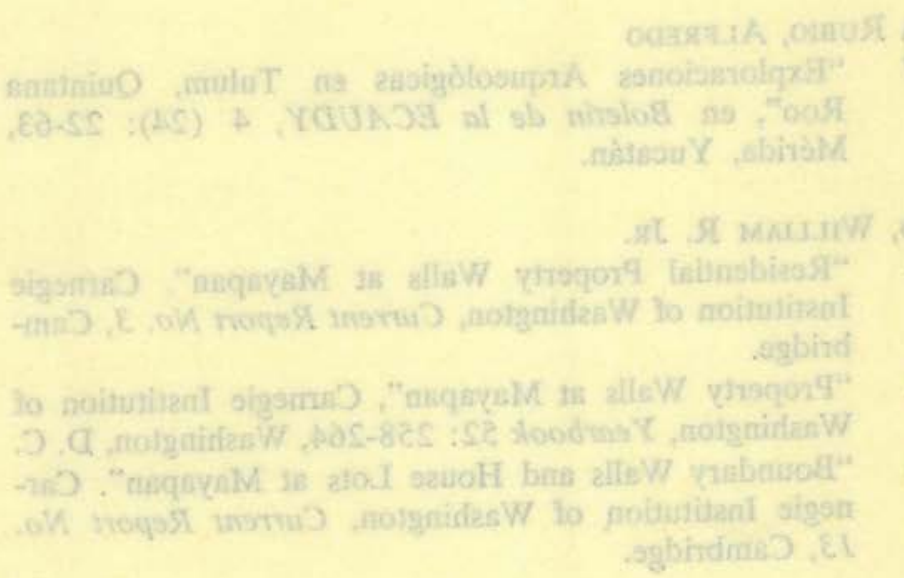


\section{BIBLIOGRAFIA}

ANDREWS, E. WyLLYS, IV

1969 The Archaeological Use and Distribution of Mollusca in the Maya Lowlands. Tulane University, Middle American Research Institute, Publ. 34, New Orleans.

-1975 y ANTHONy P. ANDREWS

1975 A Preliminary Study of the Ruins of Xcaret, Quintana Roo, Mexico, Tulane University, Middle American Research Institute, Publ. 40, New Orleans.

Arnold, Channing y F. J. T. Frost

1909 The American Egypt: A Record Travel in Yucatan, London.

Barrera Rubio, Alfredo

1977 "Exploraciones Arqueológicas en Tulum, Quintana Roo", en Boletín de la ECAUDY, 4 (24): 22-63, Mérida, Yucatán.

Bullard, William R. JR.

1952 "Residential Property Walls at Mayapan". Carnegie Institution of Washington, Current Report No. 3, Cambridge.

1953 "Property Walls at Mayapan", Carnegie Institution of Washington, Yearbook 52: 258-264, Washington, D. C.

1954 "Boundary Walls and House Lots at Mayapan". Carnegie Institution of Washington, Current Report No. 13, Cambridge.

Cardós de Méndez, Amalia

1959 El Comercio entre los Mayas Antiguos, Acta Anthropológica, época 2, tomo II, No. 1, México.

Chamberlain, Robert S.

1982 La Conquista de Yucatán, Editorial Porrúa, Biblioteca Porrúa No. 57, México.

Chapman, ANNE

1959 Puertos de Intercambio en Mesoamérica Prehistórica, Serie Histórica No. 3, México. 
Con URibe, MaRía José

1986 "Proyecto Xcaret. Informe de la Primera Temporada, Agosto-Diciembre, 1986". Mecanoescrito en el Archivo del Centro Regional Quintana Roo, Cancún, México.

1987 "Proyecto Xcaret. Informe de la Segunda Temporada, Julio-Noviembre, 1987". Mecanoescrito en el Archivo del Centro Regional Quintana Roo, Cancún, México.

En preparación

"La Pintura Mural de Xcaret, Quintana Roo".

Escalona Ramos, Alberto

1946 "Algunas Ruinas Prehispánicas en Quintana Roo", en Boletín de la Soc. Mex. de Geog. y Est., 61 (3): 513628, México.

Fernández, Miguel ÃNgel

1941 "El Templo No. 5 de Tulum, Quintana Roo", en Los Mayas Antiguos, Colegio de México, pp. 155-80.

Folan, William

1984 Coba: A Classic Maya Metropoli, Academic Press.

Freidel, David A. y Jeremy A. Sabloff

1984 Cozumel. Late Maya Settlement Patterns, Academic Press.

Garza Tarazona, Silvia y Edward M. KurJack

1984 "Organización Social y Asentamientos Mayas Prehispánicos", en Estudios de Cultura Maya, vol. XV, pp. 19-28, Centro de Estudios Mayas, UNAM, México.

GonZález de la Mata, Rocío

1984 "Xaman-Há, un Sitio Prehispánico en la Costa Oriental de Quintana Roo", en XVII Mesa Redonda de la SMA, San Cristóbal de las Casas, Chiapas, México, pp. 155165.

1979 "Playa del Carmen: Excavaciones en la Costa Oriental de Quintana Roo. Temporada 1978", en Memoria del Congreso Interno 1979, Centro Regional del Sureste, INAH, México, pp. 123-138. 
KuRJack, EdWARD

1974 Prehistoric Lowland Maya Community and Social Organization. Middle American Research Institute, Publ. 38, Tulane University, New Orleans.

LANDA, FRAY DiEgo DE

1978 Relación de las Cosas de Yucatán, Biblioteca Porrúa No. 13, Editorial Porrúa, México.

Lothrop, SAMUEL K.

1924 Tulum. An Archaeological Study of the East Coast of Yucatan, Carnegie Institution of Washington, Publ. 335, Washington.

MASON, GREGORY

1926a "Cities that Passed in a Night", en World's Work, 52: 433-39, New York.

$1926 \mathrm{~b}$ "The Shrines of a Vanished Race", en World's Work, 53: 83-89, New York.

1927 "Silver Cities of Yucatan", Putnam, New York.

1931 "Columbus came Late", New York.

1940 "South of Yesterday", New York.

Manzanilla, Linda (Ed.).

1985 Unidades Habitacionales Mesoamericanas y sus Äreas de Actividad, Serie Antropológica 76, Arqueología, Instituto de Investigaciones Antropológicas, UNAM, México.

MANZANILla, Linda

1987 Cobá, Quintana Roo. Análisis de dos Unidades Habitacionales Mayas del Horizonte Clásico, Instituto de Investigaciones Antropológicas, UNAM, México.

Miller, Arthur G.

1982 On the Edge of the Sea. Mural Painting at TancahTulum, Quintana Roo, México, Dumbarton Oaks, Washington.

Y NANCY FARRIS

1979 "Religious Syncretism in Colonial Yucatan: the Archaeological and Ethnohistorical Evidence from Tancah, Quintana Roo", en Mayan Archaeology and 
Ethnohistory, N. Hammond y G. Willey (Eds.), pp. 223-40, University of Texas Press, Austin.

\section{Pacheco Cruz, SANTIAgo}

1958 Diccionario de la Fauna Yucateca, Editorial Zamná, Mérida, México.

\section{PARSONS, JeFFREY}

1973 "Archaeological Settlement Patterns", en Annual Review of Anthropology, vol. 1, pp. 127-151.

Pollock, H. E. D., R. L. Roys, T. PRoskuriakoff Y A. Ledyard SMITH.

1962 Mayapan, Yucatan, Mexico, Carnegie Institution of Washington, Publ. 619, Washington, D. C.

Robles Castellanos, Fernando (Coord.)

1986 Informe Anual del Proyecto Arqueológico Cozumel: Temporada 1980, Cuadernos de Trabajo No. 2, Centro Regional de Yucatán, INAH, México.

1986 Informe Anual del Proyecto Arqueológico Cozumel: Temporada 1981, Cuadernos de Trabajo No. 3, Centro Regional de Yucatán, INAH, México.

1986 "A Review and Synthesis of Recent Postclassic Archaeology in Northern Yucatan", en Late Lowland Maya Civilization Classic to Postclassic, J. Sabloff y E. W. Andrews IV (Eds.), University of New Mexico Press, Albuquerque, pp. 53-98.

ROYS, RALPH L.

1957 The Political Geography of the Yucatan Maya. Carnegie Institution of Washington, Publ. 613, Washington, D. C.

RZEDOWSKy, JeRZy Y Miguel EquiHUA

1987 Flora. Atlas Cultural de México. SEP-INAH-Grupo Editorial Planeta, México.

\section{Sabloff, Jeremy y William L. Rathue}

1975 A Study of Changing Pre-Columbian Commercial Systems, the 1972-1973 Season on Cozumel, Mexico. Monographs of the Peabody Museum, No. 3. 
SÁNChez Crispín, Álvaro

1980 "Características Generales del Medio Físico de Quintana Roo", en Memorias del Simposio Quintana Roo: Problemática y Perspectivas. CIQRO-UNAM, México.

SANDERS, William T.

1955 An Archaeological Reconnaissance of Northern Quintana Roo. Carnegie Institution of Washington, Current Report No. 24, Washington, D. C.

1960 Prehistoric Ceramics and Settlement Patterns in Quintana Roo, México. Carnegie Institution of Washington, Publ. 603, Washington, D. C.

Silva Rhoads, Carlos y Concepción Hernández

1987 Estudios de Patrón de Asentamiento en Plaza del Carmen, Quintana Roo. Informe de la Temporada 19861987 del Proyecto Arqueológico Playacar, Quintana Roo, México. Mecanoescrito en los Archivos del Depto. de Salvamento Arqueológico del INAH, México.

Thомpson, J. E.

1964 "Trade relations between the Maya Highlands and Lowlands", en Estudios de Cultura Maya, 4:13-49, Centro de Estudios Mayas, UNAM, México.

VARGAS, ERNESTO

1984 "Consideraciones Generales sobre las Fortificaciones Militares en Tulum, Quintana Roo, México", en Estudios de Cultura Maya, vol. XV, UNAM, México.

1985 "Apuntes para el Análisis de Patrón de Asentamiento en Tulum", en Estudios de Cultura Maya, vol. XVI, UNAM, México.

VELÁZquez, Ricardo

1985 "Tulum: Extensión y Trazo", en Boletín de la ECAU$D Y, 12(70): 24-32$, Mérida, Yucatán, México.

VLCEK, DAVID

1978 "Muros de Delimitación Residencial en Chunchucmil. Algunos Comentarios sobre su Importancia para Inferir la Organización Social y Comunitaria de los Mayas en el Periodo Clásico", en Boletín de la ECAUDY, 5(28):55-64, Mérida, Yucatán, México. 


\section{Vokes, HaRold E. y Emily H. Vockes}

1983 Distribution of Shallow-Water Marine Mollusca, Yucatan Peninsula, Mexico. Mesoamerican Ecology Institute, Monograph No. 1, Publ. 54, Middle American Research Institute, Tulane University, New Orleans. 